\title{
КЛИНИЧЕСКИЕ РЕКОМЕНДАЦИИ
}

\section{по оказанию медицинской помощu naцuентам с болезнью Помпе}

\author{
г. Москва \\ 2015 г.
}

СОГЛАСОВАНО главным внештатным специалистом по медицинской генетике Минздрава России, Д.м.н., профессором С.И. Куцевым 


\section{Клинические рекомендации по оказанию медицинской nомощи nациентам с болезнью Помпе}

\section{Aвmоры:}

С.С. Никитин, д.м.н., Региональная общественная организация «Общество специалистов по нервно-мышечным болезням»

С.И. Куцев, д.м.н., ФГБНУ «Медико-генетический научный центр»

Е.Н. Басаргина, д.м.н., ФГАУ «Научный центр здоровья детей» Минздрава России, Научно-исследовательский институт педиатрии

С.В. Михайлова, д.м.н., ФГБУ «Российская детская клиническая больница» Минздрава России

Е.Ю. Захарова, д.м.н., ФГБНУ «Медико-генетический научный центр»

В.И. Ларионова, д.м.н., ГБОУ ВПО «Северо-Западный государственный медицинский университет им. И.И. Мечникова» Минздрава России

С.И. Полякова, д.м.н., ФГБНУ «Медико-генетический научный центр»

Н.П. Котлукова, д.м.н., ГБОУ ВПО «Российский национальный исследовательский университет им. Н.И. Пирогова» Минздрава России

Е.Н. Архипова, к.м.н., отдел нервно-мышечной патологии человека ФГБУ «Федеральный научноклинический центр детской гематологии, онкологии и иммунологии им. Дмитрия Рогачева» Минздрава России

М.О. Ковальчук, невролог, член правления Региональной общественной организации «Общество специалистов по нервно-мышечным болезням»

Н.В. Бучинская, к.м.Н., ГБОУ ВПО «Санкт-Петербургский государственный педиатрический медицинский университет» Минздрава России

Данные клинические рекомендации рассмотрены и утверждены на заседании 2-го Российского совета экспертов по болезни Помпе 24 сентября 2014 г., прошедшего в рамках 5-й Российской школы миологии в г. Санкт-Петербурге (22-25 сентября 2014 г.).

Согласованы в октябре 2014 г., утверждены главным внештатным специалистом по медицинской генетике Минздрава России д.м.н. С.И. Куцевым.

Клинические рекомендации пересмотрены и утверждены на заседании 3-го Российского совета экспертов по болезни Помпе 14 ноября 2015 г., прошедшего в рамках Международной междисциплинарной конференции «Управляй болью» в г. Москве (13-14 ноября 2015 г.).

Согласованы в ноябре 2015 г., утверждены главным внештатным специалистом по медицинской генетике Минздрава России д.м.н. С.И. Куцевым. 


\section{Методология}

Метод, использованный для сбора/селекции доказательств, - поиск в электронных базах данных.

Доказательная база для публикации - издания, вошедшие в Кокрановскую библиотеку, базы данных Excerpta medica database (EMBASE) и MEDLINE. Глубина поиска составила 5 лет.

Методами, использованными для оценки качества и силы доказательств, являлись консенсус экспертов и оценка значимости в соответствии с рейтинговой схемой (табл. 1).

Таблица 1. Рейтинговая схема для оценки силы рекомендации

\begin{tabular}{|c|c|}
\hline $\begin{array}{c}\text { Степень } \\
\text { рекомендации* }\end{array}$ & Качество доказательства \\
\hline $\begin{array}{l}\text { 1А. Сильная реко- } \\
\text { мендация. Высокая } \\
\text { доказательность }\end{array}$ & $\begin{array}{l}\text { Согласующиеся данные хорошо выполнен- } \\
\text { ных рандомизированных контролируемых } \\
\text { испытаний или неопровержимые доказа- } \\
\text { тельства в какой-либо другой форме. } \\
\text { Дальнейшие исследования вряд ли изменят } \\
\text { уверенность в оценке пользы и риска }\end{array}$ \\
\hline $\begin{array}{l}\text { 1В. Сильная } \\
\text { рекомендация. } \\
\text { Умеренная доказа- } \\
\text { тельность }\end{array}$ & $\begin{array}{l}\text { Данные рандомизированных контролируе- } \\
\text { мых испытаний с важными ограничениями } \\
\text { (противоречивые результаты, методологи- } \\
\text { ческие недостатки, косвенные или неточ- } \\
\text { ные) или очень убедительные доказательст- } \\
\text { ва в какой-либо другой форме. } \\
\text { Дальнейшие исследования (если они } \\
\text { проводятся), вероятно, окажут влияние } \\
\text { на уверенность в оценке пользы и риска } \\
\text { и могут ее изменить }\end{array}$ \\
\hline $\begin{array}{l}\text { 1С. Сильная реко- } \\
\text { мендация. Низкая } \\
\text { доказательность }\end{array}$ & $\begin{array}{l}\text { Данные из наблюдательных исследова- } \\
\text { ний, бессистемного клинического опыта } \\
\text { или из рандомизированных контролируе- } \\
\text { мых испытаний с серьезными недостатка- } \\
\text { ми. } \\
\text { Любая оценка эффекта является неопреде- } \\
\text { ленной }\end{array}$ \\
\hline $\begin{array}{l}\text { 2А. Слабая реко- } \\
\text { мендация. Высокая } \\
\text { доказательность }\end{array}$ & $\begin{array}{l}\text { Согласующиеся данные хорошо выполнен- } \\
\text { ных рандомизированных контролируемых } \\
\text { испытаний или неопровержимые доказа- } \\
\text { тельства в какой-либо другой форме. } \\
\text { Дальнейшие исследования вряд ли изменят } \\
\text { уверенность в оценке пользы и риска }\end{array}$ \\
\hline $\begin{array}{l}\text { 2В. Слабая } \\
\text { рекомендация. } \\
\text { Умеренная доказа- } \\
\text { тельность }\end{array}$ & $\begin{array}{l}\text { Данные рандомизированных контролируе- } \\
\text { мых испытаний с важными ограничениями } \\
\text { (противоречивые результаты, методологи- } \\
\text { ческие недостатки, косвенные или неточ- } \\
\text { ные) или очень убедительные доказательст- } \\
\text { ва в какой-либо другой форме. } \\
\text { Дальнейшие исследования (если они } \\
\text { проводятся), вероятно, окажут влияние } \\
\text { на уверенность в оценке пользы и риска } \\
\text { и могут ее изменить }\end{array}$ \\
\hline $\begin{array}{l}\text { 2С. Слабая реко- } \\
\text { мендация. Низкая } \\
\text { доказательность }\end{array}$ & $\begin{array}{l}\text { Данные из наблюдательных исследований, } \\
\text { бессистемного клинического опыта, } \\
\text { или из рандомизированных контролируе- } \\
\text { мых испытаний с серьезными недостатками. } \\
\text { Любая оценка эффекта является неопреде- } \\
\text { ленной }\end{array}$ \\
\hline Іифровое зн & соответствует силе рекомендации, буке \\
\hline
\end{tabular}

ное - уровню доказательности.

\section{Болезнь Помпе: общuе сведения}

Определение. Болезнь Помпе (БП), или гликогеноз II типа, - редкое мультисистемное наследственное заболевание накопления (ОМІМ: 232300), связанное с дефицитом фермента кислой мальтазы в лизосомах. Преимущественное накопление гликогена отмечается в скелетных мышцах, но в разной степени может обнаруживаться и в других органах и тканях, включая сердечную мышцу, печень, нервную систему, гладкую мускулатуру и др.

В литературе используются следующие общепринятые синонимы БП: болезнь накопления гликогена II типа (GSD-II), дефицит кислой мальтазы (AMD), гликогеноз II типа.

Эпидемиология. Точная распространенность БП неизвестна. По данным разных авторов, частота встречаемости болезни в зависимости от страны и этнической принадлежности варьирует в диапазоне от 1:40000 до 1:300000. Например, в Южном Китае и на Тайване частота классической младенческой (инфантильной) формы БП (МБП) составляет 1:40000-50000, т. е. диагностируется у 0,5$1,0 \%$ населения и является самым распространенным типом гликогеноза. Если рассматривать данные по Тайваню отдельно, показатель заболеваемости - 1:33134. По результатам скрининга новорожденных по сухому пятну крови в Австрии распространенность БП - 1:8684. В Голландии частота выявления гликогеноза II типа у младенцев составляет 1:138 000, а формы БП с поздним началом - 1:57 000. Сегодня считается, что суммарная распространенность БП - 1:40 000.

Классификация. БП относится к гликогенозам группе редких наследственных болезней нарушения метаболизма гликогена, связанных с изменением нескольких ферментов, вовлеченных в синтез и распад гликогена. К клиническим проявлениям болезни относятся патологические накопления гликогена и продуктов его метаболизма в клетках. Сегодня выделяют 8 основных типов гликогенозов. БП относится к гликогенозу II типа, связанному с недостаточностью лизосомной $\alpha-1,4-$-люкозидазы, приводящей к избыточному накоплению гликогена нормальной химической структуры в сердце, скелетных мышцах, печени, мозге.

Согласно Международной классификции болезней 10-го пересмотра (МКБ-10) заболевание относится к классу IV - болезни эндокринной системы, расстройства питания и нарушение обмена веществ, E74.0 - болезни накопления гликогена.

Всех пациентов с гликогенозом II типа независимо от дебюта отличает неуклонно прогрессирующий характер течения болезни. Продолжающееся отложение гликогена в тканях-мишенях нарушает их функцию и, в конечном итоге, приводит к необратимым структурным изменениям тканей и гибели больного. БП характеризуется полиорганной патологией, но в зависимости от времени манифестации частота вовлечения тех или иных органов и систем различна. 
Попытки классификации БП в зависимости от возраста дебюта с выделением младенческой формы с манифестацией на первом году жизни (с подразделением на раннюю, позднюю младенческие формы, форму с кардиомиопатией и без нее и т. п.), детской, ювенильной и взрослой не нашли единодушной поддержки специалистов.

Сегодня с учетом единого патогенеза гликогеноза II типа выделяют только 2 варианта БП в зависимости от времени дебюта симптомов.

1. МБП, манифестирующая в период новорожденности или в младенческом возрасте до $\leq 1$ года;

2. БП с поздним началом (БППН), возраст $>1$ года.

Каждая из форм имеет свои особенности клинического течения, алгоритмов диагностики и тактики ведения пациентов.

МБП характеризуется тяжелым прогрессирующим течением и быстрым развитием полиорганной патологии - мышечной гипотонией и слабостью, сердечной недостаточностью в результате гипертрофической кардиомиопатии, дыхательной недостаточностью на фоне слабости диафрагмы и межреберных мышц, нарушениями питания (трудности при вскармливании) из-за слабости лицевой мускулатуры и увеличения размера языка, увеличением печени. Смерть при МБП чаще всего наступает на первом году жизни от сердечно-дыхательной недостаточности.

БППН отличается от МБП более мягкими клиническими проявлениями и течением, отсутствием полиорганной патологии (поражение сердца крайне редко) и поздними осложнениями со стороны дыхательной системы в результате слабости мышц диафрагмы и межреберной мускулатуры. Обычно пациенты погибают от дыхательной недостаточности и инфекционных легочных осложнений. Летальность зависит от момента начала и последующего характера течения болезни и может наступить в детском, юношеском, взрослом или преклонном возрасте.

Более подробно клиническая картина выделенных форм БП рассмотрена ниже.

Генетический дефект при БП проявляется недостаточностью фермента кислой мальтазы (кислой $\alpha$-глюко-

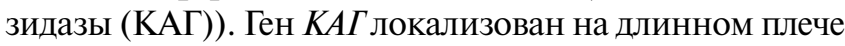
17-й хромосомы (17q25.2-q25.3), состоит из 20 экзонов и имеет размер 20 Кб. Сегодня идентифицировано более 300 мутаций этого гена, и их число постоянно растет (табл. 2).

Мутация гена приводит к снижению синтеза или полному отсутствию фермента КАГ, который относится к группе лизосомальных гидролаз. Заболевание моногенное, наследуется по аутосомно-рецессивному типу.

Патофизиология. Мутация в 2 копиях гена $K A \Gamma$, кодирующего лизосомальный энзим КАГ, отвечающий за деградацию гликогена в лизосомах, приводит к разной степени дефицита энзима. МБП развивается при зна- чительном снижении (обычно $<1 \%$ в культуре кожных фибробластов (ККФ)) или полном отсутствии активности энзима КАГ. Больше всего гликоген накапливается в скелетных мышцах и печени. Отложение или утилизация гликогена зависят от потребности организма в глюкозе. Биохимические превращения гликогена в печени способствуют поддержанию нормального уровня глюкозы в крови. В скелетных мышцах при метаболизме гликогена образуется глюкозо-6фосфат, участвующий в процессе окисления и продукции энергии, необходимой для нормальной работы мышцы (ее сокращения и расслабления).

Таблица 2. Наиболее распространенные мутации при БП

\begin{tabular}{|l|l|}
\multicolumn{1}{|c|}{ Генотип } & \multicolumn{1}{c|}{ Регион } \\
\hline $\begin{array}{l}\text { 'IVS1-13T }>\mathrm{G} \\
\text { (c.-32-13T }>\mathrm{G})\end{array}$ & Европа \\
\hline Asp645Glu (c.1935C $>$ A) & Тайвань \\
\hline Arg854X (c.2560C $>$ T) & Африка, Карибские острова \\
\hline del525T (c.525 delT) & Голландия \\
\hline del exon 18 & Голландия \\
\hline
\end{tabular}

Метаболизм гликогена происходит путем последовательного отщепления остатков глюкозы в виде глюкозо-1-фосфата. Гликозидная связь расщепляется с использованием неорганического фосфата и фермента гликогенфосфорилазы.

1. Гликогенфосфорилаза расщепляет только $\alpha-1,4-$ гликозидные связи. Поэтапное отщепление остатков глюкозы прекращается, когда до точки ветвления остается 4 мономера (реакция 1).

2. Реакция 2 заключается в переносе 3 оставшихся до точки ветвления глюкозных остатков на нередуцирующий конец соседней цепи при участии олигосахаридтрансферазы, удлиняя ее и таким образом создавая условия для действия фосфорилазы.

3. Реакция 3 происходит при участии фермента КАГ, что приводит к гидролитическому отщеплению глюкозного остатка в виде свободной глюкозы. В результате отщепления свободной глюкозы неразветвленный участок гликогена может вновь атаковаться фосфорилазой. Отсутствие или значимый дефицит КАГ приводит к массивному накоплению гликогена в лизосоме и ее перерастяжению, вплоть до разрушения.

При БП гликоген может накапливаться практически в любых тканях, при этом наблюдается преимущественное его накопление в различных органах и тканях, которое зависит от формы болезни. Так, при МБП гликоген накапливается в скелетной мускулатуре, сердечной мышце, печени, мышцах языка. Реже аномальные отложения могут встречаться в мышечном слое сосудистой стенки, определяя развитие аневризмы и мальформаций, а также в клетках центральной и периферической нервной системы. При БППН, 
в отличие от МБП, больше всего страдает скелетная мускулатура, в то время как поражение остальных органов и тканей встречается значительно реже и по тяжести поражения не сопоставимо с МБП. На поздних стадиях БППН снижение слуха, нарушение мочеиспускания и дефекации, а также случайно выявляемые внутримозговые сосудистые мальформации чаще всего считаются признаками основного генетического дефекта.

Вторичные факторы могут влиять на клиническое течение БП у пациентов с одинаковыми генетическими мутациями, что соответствует слабой корреляции между генотипом и фенотипом. Несмотря на разнообразие клинической картины, БП характеризуется неуклонно прогрессирующим течением с разными вариантами прогрессирования. Диагностика БП независимо от формы основана на оценке клинических симптомов, данных инструментальных и лабораторных обследований.

\section{Клинические проявления}

\section{младенческой формы болезни Помпе}

Во всех случаях при подозрении на МБП обязательным является уточнение семейного анамнеза (ранние смерти в семье, гибель детей в раннем детском возрасте, необычные мышечные проявления, миопатии); с учетом развития полиорганной патологии показаны расширенные лабораторные и инструментальные обследования.

Первые признаки и симптомы МБП возникают уже на 2-3-м месяцах жизни. При осмотре на приеме у педиатра обнаруживаются мышечная гипотония и прогрессирующая мышечная слабость. Лицо ребенка приобретает характерный вид: рот приоткрыт, полость рта заполнена увеличенным языком (у 1/3 младенцев), мимика ослаблена. Мать жалуется на то, что ребенок стал плохо брать грудь, быстро устает при сосании, имеет пониженную массу тела. Дальнейший осмотр выявляет плотность мышц, признаки дыхательной и сердечной недостаточности: бледность кожи, центральный цианоз, акроцианоз, гипергидроз, стонущее дыхание, участие вспомогательной мускулатуры в акте дыхания, деформация грудной клетки по типу «сердечного горба», расширение границ относительной сердечной тупости, ослабление периферической пульсации, гепатомегалия, периферические отеки. В легких аускультативно определяются жесткое дыхание, часто - проводные хрипы, ослабление дыхания слева, тахипноэ; глухие тоны сердца, систолический шум над всей областью сердца, нарушение ритма сердца (тахикардия, брадикардия, желудочковая аритмия). Для МБП характерно развитие ателектазов легких у младенцев, в основном - в нижней доле левого легкого за счет сдавления главного бронха гипертрофированным сердцем; печень увеличена. Рентгенологическое исследование грудной клетки выявляет гипертрофическую кардиомиопатию. При более позднем дебюте МБП в анамнезе присутствуют частые респираторные инфекции.

При неврологическом осмотре обнаруживается выраженная задержка развития в виде нарушения формирования моторных навыков: снижена спонтанная и произвольная двигательная активность, ребенок не держит голову, не переворачивается самостоятельно, не сидит. Слабость проксимальных мышц в положении лежа придает ребенку характерную «позу лягушки», при попытке поднять его за руки голова откидывается назад. При удержании ребенка на руке - типичный вид «вялого ребенка». Возможны избирательная гипертрофия и пальпаторная плотность мышц нижних конечностей. Сухожильные рефлексы в дебюте могут быть сохранены, но по мере прогрессирования заболевания угасают. В табл. 3 представлены основные симптомы МПБ.

Таблица 3. Основные симптомы МБП по данным литературы

\begin{tabular}{|l|c|}
\multicolumn{1}{|c|}{ Клинический симптом } & Частота, \% \\
\hline $\begin{array}{l}\text { Синдром «вялого ребенка», быстрое прогрессиро- } \\
\text { вание мышечной слабости, аксиальная гипото- } \\
\text { ния, снижение моторной активности, слабость } \\
\begin{array}{l}\text { мимических мышц, арефлексия в поздней стадии } \\
\text { заболевания, икроножные мышцы плотные } \\
\text { при пальпации }\end{array}\end{array}$ & \multicolumn{1}{|c|}{$\leq 96$} \\
\hline $\begin{array}{l}\text { Кардиомегалия, кардиомиопатия и/или сердечная } \\
\text { недостаточность }\end{array}$ & $\leq 95$ \\
\hline \begin{tabular}{l} 
Гепатомегалия \\
\hline Макроглоссия
\end{tabular} & $\leq 82$ \\
\hline $\begin{array}{l}\text { Трудности при вскармливании и снижение массы } \\
\text { тела }\end{array}$ & $\leq 50$ \\
\hline $\begin{array}{l}\text { Частые респираторные инфекции, респираторный } \\
\text { дистресс и снижение дыхательной функции }\end{array}$ & $30-40$ \\
\hline Повышение уровня креатинкиназы (КК) & 100 \\
\hline $\begin{array}{l}\text { Быстрое и неуклонное прогрессирование } \\
\text { заболевания }\end{array}$ & 100 \\
\hline
\end{tabular}

Достаточно часто к описанным выше изменениям присоединяются неспецифические нарушения в виде общего недомогания, раздражительности ребенка, повышенной потливости, рвоты и запоров. Редким, но настораживающим результатом основного метаболического дефекта является снижение слуха. В результате нарушения резорбции спинномозговой жидкости развивается гидроцефалия.

\section{Клинические проявления}

болезнu Помпе с поздним началом

МБП отличается относительной гомогенностью клинических проявлений, что нельзя сказать о БППН, это существенно затрудняет диагностику данной формы гликогеноза II типа. При одинаковом патогенезе МБП и БППН клинический спектр и тяжесть поражения различных органов и систем зависят от возраста 
пациента. После относительно благополучного развития ребенка в младенчестве при наличии гликогеноза II типа болезнь может манифестировать в любом возрасте. Независимо от времени дебюта БППН у детей или взрослых заболевание носит неуклонно прогрессирующий характер, с которым может не коррелировать выраженность мышечных и иных проявлений.

При манифесте БППН после первого года жизни (иногда в литературе эту форму БППН называют ювенильной, чтобы подчеркнуть, что болезнь манифестировала в детстве, но после первого года жизни) обнаруживается миопатический синдром, органомегалия. Наблюдается задержка формирования двигательных навыков. Вовлечение в патологический процесс сердечной мышцы вариабельно, чаще развивается дыхательная недостаточность в результате слабости диафрагмы и межреберных мышц.

Основные симптомы, выявленные при осмотре пациента с БППН с дебютом в детском возрасте, могут уменьшаться с возрастом ребенка, за исключением поражения скелетной и дыхательной мускулатуры (табл. 4).

Таблица 4. Основные клинические симптомы детской формы БППН по данным литературы

\section{Клинический симптом}

Прогрессирующая мышечная слабость с преимущественным поражением проксимальных отделов, снижение моторной активности, слабость в ногах больше, чем в руках, гипертрофия икроножных мышц, вовлечение параспинальных мышц (у детей постарше), гипотония, снижение сухожильных рефлексов, положительные приемы Говерса, миопатическая походка

Нарушения дыхания, частые респираторные инфекции, дыхательная недостаточность, диспноэ при физической нагрузке, обструктивное апноэ во время сна, ортопноэ

Повышение уровня КK

Умеренная гепатомегалия

Кардиомегалия, кардиомиопатия (менее выраженная, чем при дебюте до 1 года жизни)

Макроглоссия

Сонливость, утомляемость

Лордоз, кифоз и/или сколиоз

Нормальное психоречевое развитие, сохранный интеллект

Следует отметить, что в $95 \%$ случаев уровень сывороточной КК при БП повышается в 2-10 раз, особенно при МБП ( $\geq 2000$ Ед/л). По данным литературы, активность сывороточной КК обратно пропорциональна возрасту ( $\rho=-0,71, p<0,001)$, длительности болезни $(\rho=-0,45, p<0,001)$ и атрофии мышц $(\rho=-0,53$, $p<0,001)$.
Родители часто неправильно оценивают состояние ребенка, считая его «ленивым» и не обращаются к специалисту. В последующем у ребенка развивается нарушение осанки, появляется гиперлордоз, сколиоз, походка становится вперевалку (по типу «утиной»). Мышцы ног и тазового пояса поражаются больше, чем мышцы плечевого пояса. У детей часто развивается регионарная псевдогипертрофия мышц спины, а также симптомы ригидного позвоночника. Прогрессирование болезни приводит к нарушениям дыхания, обычно в форме ночных гиповентиляций, частых простудных заболеваний и аспирационной пневмонии. Ребенок может предъявлять жалобы на головную боль; в поведении отмечается быстрая утомляемость и снижение устойчивости к привычным нагрузкам, в основном к бегу и активным играм. Слабость мимических мышц, умеренный птоз (часто асимметричный), увеличение языка, снижение сухожильных рефлексов и остеопения также должны насторожить в отношении наличия у ребенка БППН. У детей постарше при БППН в отличие от младенцев кардиомиопатия встречается значительно реже, и практически никогда заболевание не проявляется патологией со стороны сердца.

БППН характеризуется гетерогенностью клинических проявлений, различным возрастом появления первых очевидных признаков и симптомов, разной скоростью прогрессирования болезни и выраженной слабостью мышц. При одинаковом генотипе возраст начала заболевания может быть разным и отличаться по всем перечисленным выше проявлениям.

Показано, что первые признаки БППН, которые субъективно не рассматривались пациентом как отклонение от нормы, в 76 \% случаев касались трудностей при занятиях спортом (пациенты плохо бегали, не могли подтянуться на турнике), $28 \%$ больных быстро уставали при ходьбе по лестнице, $20 \%$ испытывали затруднения при вставании с низкого стула, 17 \% уставали при обычной ходьбе и $11 \%$ не могли встать из положения лежа на спине без помощи рук.

Таким образом, при подозрении на БП у взрослого пациента необходимо детально выяснить особенности двигательного развития в детском и юношеском возрасте.

Слабость мышц - основная жалоба у взрослых пациентов с БППН, обнаруживаемая в 93 \% случаев. По паттерну распределения мышечной слабости отмечается несколько меньшая вариабельность между больными. В большинстве случаев максимальная слабость касается параспинальных мышц и мышц передней стенки живота, проксимальных отделов ног и плечевого пояса. Слабость проксимальных отделов преобладает над снижением силы в дистальных мышцах (если таковая наблюдается). Более того, в случае обнаружения слабости мышц конечностей и ее оценки через 1 год после первого осмотра больного прогрессирующее снижение мышечной силы отмечено больше для ног, 
чем для рук. В среднем сила мышц ног уменьшается на 7,1 \%, рук - на 4,0 \%. По характеру распределения мышечной слабости разные авторы отмечают следующие закономерности. Описаны большее симметричное вовлечение отводящих мышц бедер и ягодиц при относительной сохранности мышц сгибателей бедра, относительная сохранность мышц бедер по сравнению с мышцами тазового пояса и слабостью мышц разгибателей бедра. На ранних стадиях болезни изменения в мышцах могут проявляться только походкой по типу «утиной» с гиперлордозом поясничного отдела. Слабость мышц плечевого пояса чаще обнаруживается при тестировании и носит диффузный характер. Пациенты могут не предъявлять жалоб на изменение силы мышц предплечия и кисти даже на далеко зашедших стадиях болезни, когда признаки первично-мышечного поражения по типу «миопатии поясов» становятся очевидными. Достаточно часто слабость и изменение объема (атрофии) мышц плечевого пояса могут быть асимметричными, что может проявляться в отставании лопатки от грудной клетки (крыловидной лопатки) только с одной стороны или значительной асимметрии данного симптома.

Как уже говорилось выше, параспинальные мышцы и мышцы передней стенки живота могут поражаться на самых ранних стадиях БППН, что приводит к быстрой утомляемости, снижению переносимости стандартных нагрузок как на ранних, так и на поздних стадиях болезни. Важно выявить нарушение дыхательной функции вследствие слабости мышц диафрагмы и межреберных мышц. До 1/3 взрослых пациентов с БППН имеют нарушения со стороны дыхательной системы.

Рекомендуется тестирование мышц разных групп с выполнением простых заданий (табл. 5), по результатам которых можно со значительной вероятностью обосновать необходимость обследования пациента на наличие БППН.
На основании собранного анамнеза и осмотра пациента крайне важно выделить настораживающие симптомы БППН:

• слабость мышц передней стенки живота;

- слабость параспинальных мышц (лордоз, кифоз, сколиоз);

- слабость ягодичных мышц и трудность удержания равновесия при вставании;

- сохранность силы четырехглавых мышц при слабости мышц других отделов;

- слабость сгибателей шеи;

- слабость диафрагмы, одышка;

- слабость мышц языка;

- слабость мимических мышц, особенно асимметричная;

- относительно невысокие показатели КК при наличии миопатического синдрома;

- утренняя головная боль, тахикардия, дневная сонливость, необычная утомляемость;

- случайно выявленные (асимптомные) мальформации сосудов головного мозга.

\section{Дифференциальная диагностика}

Сложность диагностики БППН определяется отсутствием специфических клинических симптомов, характерных для большинства нервно-мышечных болезней, а также разнообразием их сочетания, временем появления и тяжести в процессе развития болезни. Дифференциальная диагностика МБП включает все заболевания, основным клиническим проявлением которых является синдром «вялого ребенка». Перечень основных заболеваний, входящих в дифференциальный диагноз при БПНП, представлен в табл. 6.

\section{Дuагностика болезнu Помпе}

Принципы постановки диагноза «гликогеноз II типа» в целом одинаковы для МБП и БППН и на-

Таблица 5. Тестирование мышц на наличие БППН (no Hagemans, 2005)

\begin{tabular}{|c|c|c|c|}
\hline \multirow{2}{*}{ Задание } & \multicolumn{3}{|c|}{ Число пациентов, выполнивших задание, \% } \\
\hline & $\begin{array}{l}\text { задание выполнено } \\
\text { без труда }\end{array}$ & $\begin{array}{l}\text { задание выполнено } \\
\text { с трудом }\end{array}$ & задание не выполнено \\
\hline Поднять руки над головой & 55 & 29 & 16 \\
\hline $\begin{array}{l}\text { Принять вертикальное положение из положения } \\
\text { наклонившись вперед }\end{array}$ & 14 & 45 & 41 \\
\hline Встать с низкого стула & 12 & 53 & 35 \\
\hline Встать без помощи рук из положения лежа на спине & 8 & 37 & 55 \\
\hline Подпрыгнуть на месте & 6 & 29 & 65 \\
\hline Ходьба вверх/вниз по лестнице & 2 & 57 & 41 \\
\hline Поднять ноги в положении лежа & 2 & 43 & 55 \\
\hline Подняться с корточек & 2 & 22 & 76 \\
\hline
\end{tabular}


Таблица 6. Основные заболевания, рассматриваемые при дифференциальной диагностике БППН

\begin{tabular}{|c|c|c|}
\hline Тип нарушения & Диагноз & Основной схожий симптом \\
\hline Мышечные дистрофии & $\begin{array}{l}\text { Поясно-конечностная мышечная дистрофия } \\
\text { Дистрофинопатии (миодистрофия Дюшенна, Беккера) } \\
\text { Миофибриллярная миопатия } \\
\text { Миотоническая дистрофия II типа } \\
\text { Плечелопаточная миодистрофия } \\
\text { Болезнь Данона } \\
\text { Х-сцепленная миопатия } \\
\text { Лице-лопаточно-конечностная мышечная дистрофия }\end{array}$ & $\begin{array}{l}\text { Прогрессирующая слабость мышц пояса, } \\
\text { нижних конечностей, крыловидные ло- } \\
\text { патки, крампи, повышение уровня КК }\end{array}$ \\
\hline Воспалительная миопатия & $\begin{array}{l}\text { Полимиозит } \\
\text { Миозит с включениями }\end{array}$ & $\begin{array}{l}\text { Постепенно развивающаяся слабость } \\
\text { мышц, повышение уровня КK }\end{array}$ \\
\hline Врожденные миопатии & $\begin{array}{l}\text { Немалиновая миопатия } \\
\text { Болезнь центрального стержня и мультистержневая миопатия } \\
\text { Центронуклеарная миопатия } \\
\text { Миопатия с гиалиновыми тельцами } \\
\text { Прочие врожденные миопатии }\end{array}$ & $\begin{array}{l}\text { Мышечная слабость, гипотония при нор- } \\
\text { мальном или умеренно повышенном } \\
\text { уровне KK, наличии скелетных наруше- } \\
\text { ний }\end{array}$ \\
\hline Метаболические миопатии & $\begin{array}{l}\text { Гликогенозы типов IIIa, IV, V и VII } \\
\text { Болезнь Мак-Ардля (поздняя форма) } \\
\text { Митохондриальные миопатии } \\
\text { Жировые миопатии }\end{array}$ & $\begin{array}{l}\text { Гипотония, гепатомегалия у детей, } \\
\text { слабость мышц, утомляемость, снижение } \\
\text { устойчивости к нагрузкам, повышение } \\
\text { уровня КK }\end{array}$ \\
\hline Болезни мотонейрона & $\begin{array}{l}\text { Спинальные мышечные атрофии 1-го и 3-го типов } \\
\text { Бульбоспинальная амиотрофия (болезнь Кеннеди) } \\
\text { Боковой амиотрофический склероз }\end{array}$ & $\begin{array}{l}\text { Слабость мышц, нарушение дыхания, } \\
\text { атрофия мышц, возможно повышение } \\
\text { уровня КK }\end{array}$ \\
\hline $\begin{array}{l}\text { Болезни нервно-мышеч- } \\
\text { ной передачи }\end{array}$ & $\begin{array}{l}\text { Миастения Гравис } \\
\text { Врожденные миастенические синдромы } \\
\text { Синдром Ламберта-Итона }\end{array}$ & $\begin{array}{l}\text { Нарушение дыхания, слабость мышц, } \\
\text { утомляемость }\end{array}$ \\
\hline $\begin{array}{l}\text { Асимптомное повышение } \\
\text { уровня КK }\end{array}$ & Неустановленный диагноз & Повышение уровня КK \\
\hline
\end{tabular}

правлены на обнаружение измененной активности соответствующего фермента.

Часто диагностика МБП начинается с выявления кардиомегалии, дыхательной недостаточности, миопатического синдрома и дисфункции желудочно-кишечного тракта, т. е. с выяснения причины, обусловливающей обративший на себя внимание синдром.

Рекомендуемые исследования при МБП.

1. Клинически: осмотр педиатра (в младенческом и детском возрасте), невролога, кардиолога.

2. Инструментальное исследование:

- нервно-мышечной системы (стимуляционная и игольчатая электромиография);

- сердца (рентгенограмма грудной клетки, электрокардиография (ЭКГ), эхокардиография (ЭхоКГ));

- легких (рентгенограмма грудной клетки, пульсоксиметрия, капнография, полисомнография). Оценка функции внешнего дыхания обязательна в положении стоя и лежа с определением разницы в показателях;

- желудочно-кишечного тракта (ультразвуковое исследование печени, поджелудочной железы).

3. Лабораторная диагностика: биохимический анализ крови с определением уровня аланинаминотрансферазы (АЛТ), аспартатаминотрансферазы (АСТ), сывороточной креатинкиназы (KK), лактатдегидрогеназы (ЛДГ). Анализ активности КАГ по сухому пятну крови.
4. Анализ мышечного биоптата (по показаниям):

- гистологическое исследование;

- иммуногистохимическое исследование;

- электронная микроскопия.

5. Генетические методы исследования (ДНК-анализ).

Перечисленные клинико-инструментальные методы исследования необходимы для диагностики и дифференциальной диагностики миопатических синдромов у пациентов, в том числе у детей в возрасте до 1 года.

\section{Лабораторная диагностика, подтверждающая болезнь Помпе}

Диагноз БП обязательно должен быть подтвержден лабораторными методами. «Золотым стандартом» диагностики БП является определение активности фермента КАГ в тканях, которая у пациентов с МБП не превышает $1 \%$ от нормы, а у больных с БППН может составлять до $30 \%$. Выявлена корреляция между степенью тяжести заболевания и активностью фермента. При этом биохимическая подтверждающая диагностика БП представляет определенные трудности. Это связано с наличием в лейкоцитах периферической крови фермента нейтральной мальтазы, близкого по своей субстратной специфичности к КАГ. Присутствие этого фермента может искажать значения активности КАГ и приводить к ложноотрицательным результатам, поэтому иногда рекомендуют в качестве 
ткани для исследования использовать ККФ или биоптат мышечной ткани, в которых нейтральная мальтаза не экспрессируется. В последние годы применяют тест с добавлением ингибитора нейтральной мальтазы, что позволяет измерять активность только КАГ.

Наиболее удобным современным методом остается определение активности ферментов в пятнах высушенной крови с помощью тандемной масс-спектрометрии. В табл. 7 представлены рекомендуемые подходы по определению активности КАГ в различных тканях.

Методы молекулярно-генетического анализа могут быть полезны в качестве дополнительного теста при подтверждающей диагностике БП, если недоступен биологический материал пробанда, а также для пренатальной и преимплантационной диагностики. Однако, поскольку в гене $K A Г$ описано большое число уникальных мутаций, а также полиморфных вариантов, могут возникнуть трудности в интерпретации впервые выявленных изменений нуклеотидной последовательности.

Согласно рекомендациям международной группы экспертов для подтверждения лабораторного диагноза БП после выявления снижения активности фермента в образце крови необходимо провести повторное определение активности фермента в другом образце биологического материала (мышечной ткани, ККФ), а для биохимического диагноза - ДНК-анализ.

Отметим, что клинический диагноз БП - прежде всего фенотипический и основывается на клинической картине заболевания в сочетании с лабораторным подтверждением снижения или отсутствия активности КАГ.

\section{Лечение пациентов с болезнью Помпе}

Современное лечение БП заключается в назначении пожизненной ферментной заместительной терапии (ФЗТ) рекомбинантной человеческой КАГ.

Единственным препаратом для патогенетической ФЗТ при БП является алглюкозидаза альфа, зарегистрированная в России как Майозайм.

Препарат Майозайм (Код АТХ: А16АВ07) - рекомбинантный фермент, синтезируемый клеточной линией, полученной из яичников китайских хомячков. Он восполняет активность лизосомальной КАГ, что приводит к стабилизации или восстановлению функции сердечной и скелетных мышц (включая дыхательные мышцы). Препарат хорошо переносится, не имеет выраженных побочных эффектов. Показан для долговременной ФЗТ у больных всех возрастов с подтвержденным диагнозом БП.

На данный момент эффективность и безопасность Майозайма оценены в клинических испытаниях как у детей, так и у взрослых. Законченные и опубликованные исследования по лечению БП были проведены с участием более 500 больных. Безопасность и хорошая переносимость терапии алглюкозидазой альфа подтверждены клиническими наблюдениями на протяжении более 10 лет с участием свыше 1800 пациентов.
Таблица 7. Определение активности КАГ в различных тканях

\begin{tabular}{|c|c|}
\hline $\begin{array}{l}\text { Образец биологи- } \\
\text { ческого материала }\end{array}$ & $\begin{array}{c}\text { Характеристика теста, требование } \\
\text { к транспортировке биологического материала }\end{array}$ \\
\hline $\begin{array}{l}\text { Пятно } \\
\text { высушенной крови }\end{array}$ & $\begin{array}{l}\text { Минимально инвазивный тест, требуется } \\
\text { небольшой объем образца, может при- } \\
\text { меняться для массового и селективного } \\
\text { скрининга на БП } \\
\text { Транспортировка образца при нормальной } \\
\text { температуре в течение нескольких дней } \\
\text { Фермент сохраняет активность несколько } \\
\text { месяцев при температуре }+4 \text { ㄷ }\end{array}$ \\
\hline $\begin{array}{l}\text { Лейкоциты } \\
\text { переферической } \\
\text { крови }\end{array}$ & $\begin{array}{l}\text { Минимально инвазивный тест, требуются } \\
\text { образцы цельной крови в гепаринизиро- } \\
\text { ванной пробирке. Необходимо применять } \\
\text { ингибитор МGA } \\
\text { Транспортировка образца при температуре } \\
\text { от } 0 \text { до }+4 \text { `C в течение } \leq 24 \text { ч }\end{array}$ \\
\hline $\begin{array}{l}\text { Фракция } \\
\text { лимфоцитов }\end{array}$ & $\begin{array}{l}\text { Минимально инвазивный тест, требуются } \\
\text { образцы цельной крови в гепаринизиро- } \\
\text { ванной пробирке. Необходимо выполне- } \\
\text { ние дополнительного этапа - выделение } \\
\text { лимфоцитов, требующее определенного } \\
\text { опыта работы } \\
\text { Транспортировка образца при температуре } \\
\text { от } 0 \text { до }+4{ }^{\circ} \mathrm{C} \text { в течение } \leq 24 \text { ч }\end{array}$ \\
\hline ККФ & $\begin{array}{l}\text { Инвазивный тест. Обеспечивает надежный } \\
\text { анализ фермента КАГ. Не требует примене- } \\
\text { ния ингибитора МGA } \\
\text { Необходимы 2-4 нед для получения ККФ } \\
\text { Ограниченное число лабораторий имеет } \\
\text { возможности для культивирования клеток }\end{array}$ \\
\hline $\begin{array}{l}\text { Биоптат } \\
\text { мышечной ткани }\end{array}$ & $\begin{array}{l}\text { Инвазивный тест, выполняется только } \\
\text { в условиях стационара. Обеспечивает на- } \\
\text { дежный анализ фермента КАГ. Возможно } \\
\text { проведение гистологического исследования } \\
\text { для дифференциальной диагностики БП } \\
\text { и других миопатий } \\
\text { Ограниченное число лабораторий имеет } \\
\text { возможности для исследований мышечной } \\
\text { ткани }\end{array}$ \\
\hline
\end{tabular}

Препарат выпускается во флаконах, количество лиофилизата в которых эквивалентно 50 мг активного вещества. Вводится внутривенно капельно в дозировке 20 мг/кг массы тела пациента.

Ф3Т позволяет сохранить жизнь пациентам с БП, улучшает ее качество и замедляет прогрессирование болезни. Раннее начало терапии очень важно, так как позволяет добиться наиболее хороших клинических исходов. Доказано, что применение ФЗТ при МБП уменьшает риск смерти на $99 \%$, а необходимость инвазивной вентиляции легких - на $92 \%$. Своевременное назначение терапии алглюкозидазой альфа вызывает обратный ход кардиомиопатии у пациентов с МБП, улучшает показатели мышечной силы, двигательной активности и стабилизирует состояние дыхательной системы. Терапия пациентов с БППН препаратом Майозайм замедляет прогрессирование болезни, улучшая состояние костно-мышечной системы и стабилизируя состояние дыхательной системы, удлиняет период жизни пациентов до наступления необходимости в вентиляции легких и потребности в кресле-коляске. 
В связи с этим как можно более раннее начало ФЗТ алглюкозидазой альфа и отсутствие перерывов в лечении является жизненно важной мерой, которая позволит предотвратить раннюю инвалидизацию, снизит риск смерти больных и их перехода на инвазивную вентиляцию легких, улучшит социальную адаптацию пациентов, значительно повысит качество их жизни и функциональную независимость.

При наличии подтвержденного диагноза БП независимо от возраста больного патогенетическая терапия алглюкозидазой альфа должна быть начата незамедлительно. Жизненная важность раннего начала терапии подчеркнута во всех международных рекомендациях по лечению БП.

Ведение пациентов с БП предполагает мультидисциплинарный подход с обязательным участием неврологов (особенно специалистов по нервно-мышечным болезням), генетиков, кардиологов, пульмонологов, гастроэнтерологов, физиотерапевтов и врачей других специальностей, имеющих опыт в лечении этого редкого заболевания.

\section{Особенности ведения пациентов с младенческой формой болезни Помпе}

Пациентам с МБП жизненно важно немедленное назначение ФЗТ при установлении диагноза.

Особенности проведения ФЗТ при МБП:

- не кормить ребенка за 3-4 ч до проведения инфузии (предупреждение аспирации, возможное проведение реанимационных мероприятий);

- разведение препарата в минимальном объеме;

- введение препарата при первых инфузиях должно проводится в центральный венозный катетер или если препарат вводится в периферический венозный катетер необходимо иметь 2 доступа, в дальнейшем рекомендуется установка инфузионной порт-системы;

- инфузии с ограниченной скоростью (повышение на 0,5-1 мл/ч каждые 30-60 мин) с учетом высокого риска декомпенсации сердечной недостаточности на фоне гиперволемии;

- проведение первых 3 инфузий в отделении реанимации и интенсивной терапии с участием реаниматолога. нахождение в данном отделении в течение 3-6 ч после завершения процедурым;

- инсуффляция увлаженного кислорода через маску;

- мониторинг витальных функций по прикроватному монитору (частота сердечных сокращений, артериальное давление (АД), сатурация) во время проведения инфузии или по показаниям (зависит от тяжести состояния).

Мониторирование пациента с МБП должно включать контроль:

- сердечно-сосудистой системы. Ребенок с МБП в процессе всего периода лечения нуждается в наблюдении кардиолога, первоначально - в условиях стационара, а при стабилизации состояния - по показаниям, но не реже 1 раза в 3 мес. Сроки пребы- вания в стационаре зависят от тяжести состояния больного. Уход носит индивидуальный характер:

- проведение ЭКГ в стационаре обязательно (при необходимости суточное мониторирование ЭКГ в целях своевременного выявления нарушений ритма сердца). В последующем при улучшении или стабилизации состояния выполнять ЭКГ нужно ежемесячно первые 3 мес или чаще по показаниям, далее - каждые 3 мес или по показаниям,

- ЭхоКГ-контроль каждые 7-14 дней в первые 12-24 нед ФЗТ (контроль транзиторного снижения сократимости миокарда, которое может сопровождаться нарастанием проявлений сердечной недостаточности и требует коррекции симптоматической терапии), далее - ежемесячно или по показаниям. По достижении ребенком 1 года ЭхоКГ выполняется 1 раз в 3 мес или по показаниям,

- контроль уровня натрийуретический гормон В-типа NT-proBNP каждые 3 мес или по показаниям до достижения ребенком 1 года, далее выполняется 1 раз в 3-6 мес или по показаниям,

- строгий ежедневный контроль объема потребляемой жидкости (ограничение объема до 2/3 от физиологической потребности), контроль питания, парентеральной инфузионной терапии в целях предупреждения перегрузки или обезвоживания,

- применение препаратов для лечения сердечной недостаточности (сердечные гликозиды, диуретики, $\beta$-блокаторы, ингибиторы ангиотензинпревращающего фермента). Назначение антиаритмических препаратов разных классов с учетом высокой аритмогенности миокарда. Важно: некорректное использование препаратов может усугубить состояние больного;

- дыхательной системы. При каждом осмотре пациента необходима оценка респираторного статуса (характер и частота дыхания при бодрствовании и во время сна, ведение родителями пациента респираторного дневника):

- оценка легочной функции и газообмена при установлении диагноза, каждом визите пациента и изменении клинического состояния (присоединении вирусной инфекции). Проведение рентгенограммы грудной клетки при установлении диагноза и по показаниям,

- полисомнография после установления диагноза и по клиническим показаниям (выявление и профилактика апноэ во сне),

- при необходимости (скопление секрета, рефлюкс) санация верхних дыхательных путей,

- микробиологическое исследование трахеального аспирата для оценки микробного статуса и необходимости проведения антибактериальной и/или противогрибковой терапии,

- оценка функции внешнего дыхания во время сна и/или бодрствования при появлении и/или на- 
растании жалоб на усталость, возникновении периферического цианоза, апноэ во сне, падении жизненной емкости легких ниже 40-50 \%, уменьшении сатурации и неэффективности ее коррекции на фоне инсуфляций кислорода у детей раннего возраста,

- неинвазивная кислородная поддержка (создание положительного давления) при развитии гипоксемии, обструктивном синдроме,

- лечение любых инфекций дыхательных путей должно носить агрессивный характер, назначение антибактериальной терапии проводится в максимальных терапевтических дозировках,

- обучение родителей пользованию небулайзером, отсосом;

- желудочно-кишечного тракта:

- контроль роста и массы тела еженедельно, ежемесячно, ежеквартально,

- включение в рацион питания специализированных высококалорийных и высокобелковых, антирефлюксных смесей,

- зондовое или совмещенное пероральное и зондовое кормление при сохранении адекватного глотания и отсутствии поперхивания,

- назодуоденальное зондовое кормление при сохранении рефлюкса и высоком риске аспирации,

- оральная стимуляция, сосание соски, гимнастика для поддержания нормального развития навыков глотания и устной речи;

- скелетно-мышечной системы:

- поддержка максимального уровня функций скелетно-мышечного аппарата для предотвращения и минимизации вторичных осложнений (развитие контрактур, мышечных атрофий, компенсаторной деформации скелета, остеопении, остеопороза),

- при проведении реабилитационных мероприятий избегать чрезмерных нагрузок. Регулярно - физиотерапевтические процедуры, массаж, лечебная физкультура, логопедия, респираторная терапия (дыхательная гимнастика), обучение самообслуживанию и использованию вспомогательных приспособлений (зависит от возраста ребенка). По показаниям - занятия с логопедом, сурдолгом,

- применение препаратов кальция, магния, витамина D.

Осмотр невролога с оценкой моторных возможностей и нервно-психического развития ребенка (по шкале Альберта моторного развития младенцев (Приложение 1)) проводится каждые 3-6 мес для детей в возрасте до 5 лет и ежегодно для более старших пациентов. Тестирование слуха должно выполняться ежегодно или по клиническим показаниям.

Общетерапевтические мероприятия при МБП:

- агрессивное лечение сопутствующих заболеваний, часто с эмпирическим назначением антибактериальной терапии;
• вакцинация по индивидуальному графику включает помимо вакцин в рамках национального календаря прививок, вакцину против респираторно-синцитиальной инфекции, сезонную вакцину от гриппа, пневмококковую вакцину. Диагноз МБП не является противопоказанием для проведения вакцинации.

\section{Особенности выполнения анестезиологических и хирургических мероприятий:}

- консолидация хирургических процедур, требующих анестезиологического пособия;

- максимальное избегание интубации или минимизация длительности ее проведения.

Прогноз болезни зависит от возраста ее дебюта, количества вовлеченных систем организма, в том числе степени и тяжести поражения мышечного аппарата (скелетной, дыхательной, сердечной мускулатур), скорости прогрессирования, времени начала Ф3Т.

\section{Особенности ведения пациентов}

\section{с болезнью Помпе с поздним началом}

По данным последних исследований, снижение минеральной плотности костей встречается у 67 \% пациентов с БП. Остеопения и остеопороз обнаруживаются как при МБП, так и при БППН. Неустойчивость при ходьбе, сложность поддержания равновесия в результате мышечной слабости в сочетании с остеопорозом могут приводить к переломам костей и позвоночника. Все пациенты с БППН независимо от степени обездвиженности (например, нуждающиеся в креслекаталке) должны быть обучены мерам предосторожности для профилактики падения и переломов в быту. Обязательными являются ежегодные исследования минеральной плотности костей для своевременной коррекции получаемого лечения по поводу остеопении и остеопороза. Пациенты с БП и члены их семьи должны быть информированы о всех последствиях неадекватного отношения к проблеме остеопороза. Следует настойчиво рекомендовать больному с нарушением походки и равновесия пользоваться вспомогательными предметами - тростью, ходунками, а при необходимости использовать механические средства передвижения (кресло-каталку и др.). Необходимо своевременно назначать препараты витамина D, кальция, бисфосфонатов по схемам, рекомендованным для общей популяции. Пациенты с БППН должны регулярно обследоваться эндокринологом. Большое значение имеет правильный образ жизни с адекватным распределением нагрузок, занятий лечебной физкультурой под контролем информированного инструктора.

Ведение пациентов с БП с выявленными мальформациями или иной патологией сосудов головного мозга не должно отличаться от ведения пациентов без БП с аналогичными патологиями.

В табл. 8 представлен график необходимых обследований пациентов с диагностированной БП. 
Таблица 8. График обследований пациентов с БП
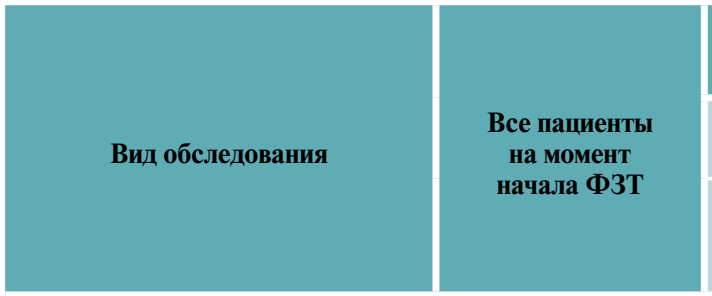

\begin{tabular}{|c|c|c|c|c|}
\hline \multicolumn{3}{|c|}{ Пациенты в возрасте менее 5 лет } & \multicolumn{2}{|c|}{$\begin{array}{c}\text { Пациенты в возрасте } 5 \text { лет } \\
\text { и старше }\end{array}$} \\
\hline \multicolumn{5}{|c|}{ частота обследования } \\
\hline $\begin{array}{l}\text { каждые } \\
3 \text { мес }\end{array}$ & $\begin{array}{c}\text { каждые } \\
6 \text { мес }\end{array}$ & $\begin{array}{c}\text { каждые } \\
12 \text { мес }\end{array}$ & $\begin{array}{c}\text { каждые } \\
6 \text { мес }\end{array}$ & $\begin{array}{l}\text { каждые } \\
12 \text { мес }\end{array}$ \\
\hline
\end{tabular}

Клинический статус

Измерение роста, массы тела, окружности головы у детей

Измерение АД, температуры тела

Анализ крови*

Анализ мочи**

Рентгенография органов грудной клетки

\section{ЭКГ}

\section{ЭХоКГ}

Аудиометрия

Оценка остроты зрения

Оценка когнитивного статуса

Оценка функции внешнего дыхания

Оценка моторного статуса по шкалам и тесту 6-минутной ходьбы
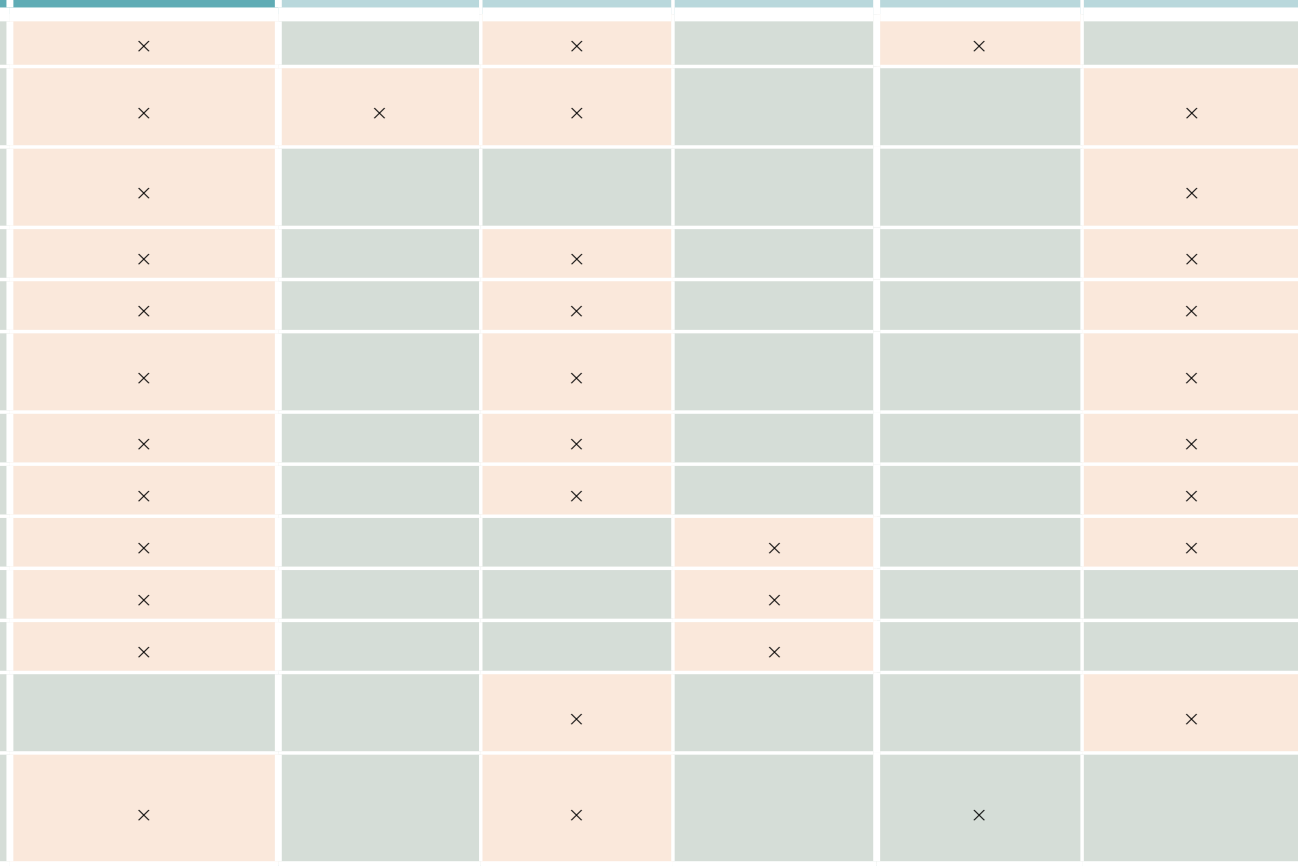

Оценка качества жизни

\section{Опросник SF-36}

Роттердамская шкала инвалидности

Шкала степени усталости

*Анализ крови должен включать: АЛТ, АСТ, ЛДГ, КК (МВ-фракция), альбумин сыворотки, протромбиновое время, частичное тромбопластиновое время, общий билирубин, сывороточный креатинин.

**Анализ мочи должен включать: креатинин мочи, белок, скорость клубочковой фильтрации.

*** Используемые шкалы: шкала Альберта моторного развития младенцев (приложение 1), сила мыши по шкале Комитета медицинских исследований (приложение 2), шкала Скотта для оценки мышечного статуса (приложение 3), функциональные классы шкалы Виньоса (приложение 4), тест 6-минутной ходьбы (приложение 5).

\section{Медико-генетическое консультирование,}

\section{пренатальная u предимплантационная диагностика}

Семьям с больными детьми рекомендуется медико-генетическое консультирование в целях определения генетического риска. Как и при других аутосомнорецессивных заболеваниях, для каждой беременности риск рождения ребенка с БП составляет $25 \%$. Возможно проведение пренатальной и предимплантационной диагностики в специализированных диагностических лабораториях и медицинских центрах. Пренатальная диагностика выполняется молекулярно-генетическими или биохимическими методами, путем исследования ДНК, выделенной из биоптата ворсин хориона на 9-11-й нед беременности и/или клеток амниотической жидкости, плодной крови на 20-22-й нед беременности. 
Приложение 1

\section{Шкала Альберта моторного развития младенцев}

Фамилия, имя

Идентификационный номер

ФИО исследователя

Место проведения исследования
Дата исследования

Дата рождения

Хронологический возраст

Скорректированный возраст число/месяц/год

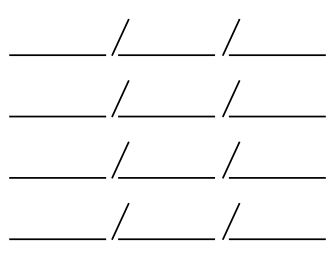

\begin{tabular}{|l|l|l|l|}
\hline \multicolumn{1}{|c|}{ Поза } & $\begin{array}{c}\text { Предшествуюие } \\
\text { засчитанные пункты }\end{array}$ & $\begin{array}{c}\text { Пункты, засчитанные } \\
\text { в «окне» }\end{array}$ & Балл по подшкале \\
\hline $\begin{array}{l}\text { Положение } \\
\text { на животе }\end{array}$ & & & \\
\hline $\begin{array}{l}\text { Положение } \\
\text { на спине }\end{array}$ & & & \\
\hline Посадка & & & \\
\hline Вставание & & & \\
\hline
\end{tabular}

Общий балл: Процентиль:

Примечания/рекомендации: 


\section{Шкала оценкu моторного развитuя младенцев}

\begin{tabular}{|c|c|c|}
\hline \multicolumn{2}{|c|}{ Вид движения } & Описание движения \\
\hline \multirow{6}{*}{$\begin{array}{l}\text { Положение } \\
\text { на животе }\end{array}$} & & $\begin{array}{l}\text { Положение лежа на животе (1) } \\
\text { Физиологическая флексия. Поворачивает } \\
\text { голову для отведения носа от поверхности }\end{array}$ \\
\hline & & $\begin{array}{l}\text { Положение лежа на животе (2) } \\
\text { Симметрично поднимает голову под углом } 45^{\circ} . \\
\text { Не способен удерживать голову на одной линии } \\
\text { с туловищем }\end{array}$ \\
\hline & & $\begin{array}{l}\text { Положение на животе с опорой } \\
\text { Локти находятся позади плеч. Без поддержки } \\
\text { поднимает голову под углом } 45^{\circ}\end{array}$ \\
\hline & & $\begin{array}{l}\text { Опора на предплечья (1) } \\
\text { Поднимает и удерживает голову под углом } \geq 45^{\circ} \text {. } \\
\text { Локти на одной линии с плечами. Грудная } \\
\text { клетка размещается по центру }\end{array}$ \\
\hline & & $\begin{array}{l}\text { Подвижность в положении на животе } \\
\text { Поднимает голову под углом до } 90^{\circ} . \text { Некон- } \\
\text { тролируемые попытки переноса тела }\end{array}$ \\
\hline & & $\begin{array}{l}\text { Опора на предплечья (2) } \\
\text { Локти находятся перед плечами. Активное } \\
\text { подтягивание подбородка с вытягиванием шеи }\end{array}$ \\
\hline $\begin{array}{l}\text { Положение } \\
\text { на спине }\end{array}$ & & $\begin{array}{l}\text { Положение лежа на спине (1) } \\
\text { Физиологическая флексия. Поворачивает } \\
\text { голову, подносит руку ко рту. Беспорядочные } \\
\text { движения руками и ногами }\end{array}$ \\
\hline
\end{tabular}




\begin{tabular}{|c|c|}
\hline \multirow{4}{*}{$\begin{array}{l}\text { Положение } \\
\text { на спине }\end{array}$} & $\begin{array}{l}\text { Положение лежа на спине (2) } \\
\text { Поворот головы к средней линии. Необязатель- } \\
\text { ный асимметричный шейный тонический } \\
\text { рефлекс }\end{array}$ \\
\hline & $\begin{array}{l}\text { Положение лежа на спине (3) } \\
\text { Голова на одной линии с туловищем. Двигает } \\
\text { руками, но не способен поднести руки к сред- } \\
\text { ней линии }\end{array}$ \\
\hline & $\begin{array}{l}\text { Положение лежа на спине (4) } \\
\text { Активность сгибателей шеи с подтягиванием } \\
\text { подбородка. Подносит руки к средней линии }\end{array}$ \\
\hline & $\begin{array}{l}\text { Поднесение рук к коленям } \\
\text { Подтягивание подбородка. Достает руками } \\
\text { до коленей. Активность брюшных мышц }\end{array}$ \\
\hline \multirow{3}{*}{ Посадка } & $\begin{array}{l}\text { Посадка с поддержкой } \\
\text { Поднимает и кратковременно удерживает } \\
\text { голову на одной линии с туловищем }\end{array}$ \\
\hline & $\begin{array}{l}\text { Посадка с опорой на руки } \\
\text { Удерживает голову на одной линии с тулови- } \\
\text { щем. Кратковременно опирается на руки }\end{array}$ \\
\hline & $\begin{array}{l}\text { Подтягивание в сидячее положение } \\
\text { Подтягивает подбородок. Голова на одной } \\
\text { линии с туловищем или впереди }\end{array}$ \\
\hline Вставание & $\begin{array}{l}\text { Опора на ноги с поддержкой (1) } \\
\text { Возможно попеременное сгибание в тазобед- } \\
\text { ренном и коленном суставах }\end{array}$ \\
\hline
\end{tabular}




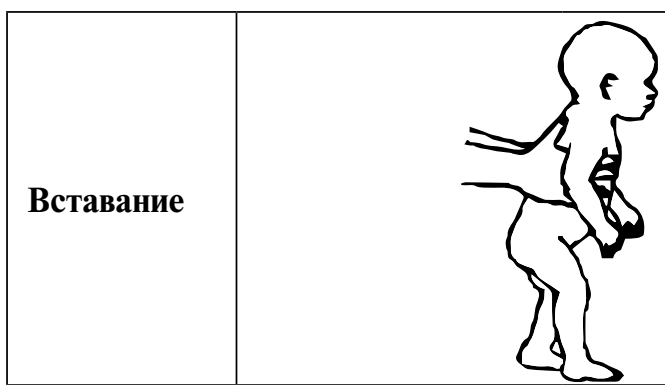

Опора на ноги с поддержкой (2)

Голова на одной линии с туловищем. Бедра находятся позади плеч. Разнообразные движения ногами

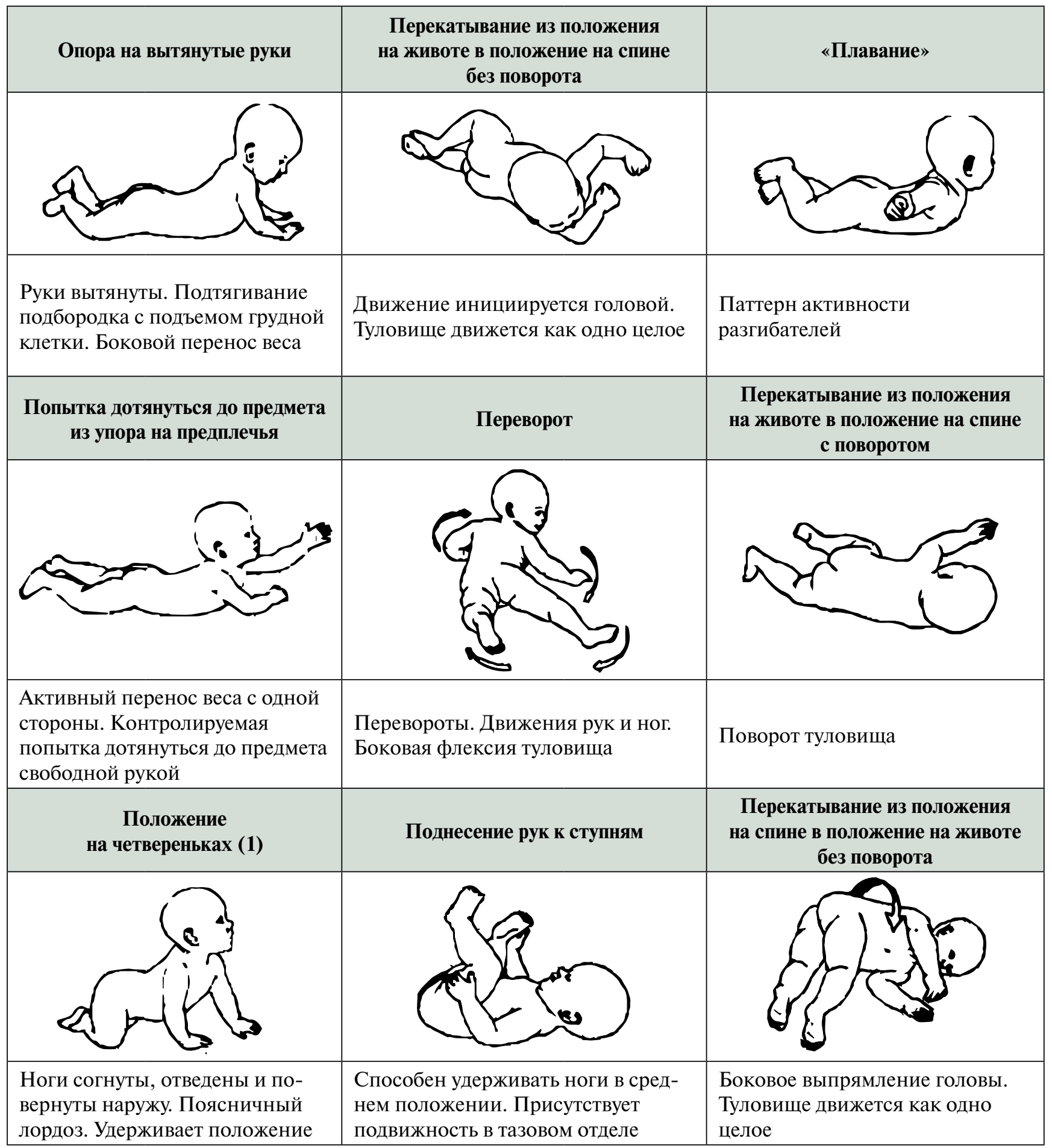




\begin{tabular}{|c|c|c|}
\hline $\begin{array}{c}\text { Перекатывание из положения } \\
\text { на спине в положение на животе } \\
\text { с поворотом } \\
\end{array}$ & Активное вытягивание & Посадка без поддержки \\
\hline Поворот туловища & Вытягивается, отталкивась ногами & $\begin{array}{l}\text { Приведение лопаток } \\
\text { и разгибание плеч. Не способен } \\
\text { удержать положение }\end{array}$ \\
\hline Посадка с опорой на руки & $\begin{array}{c}\text { Посадка без поддержки } \\
\text { и без опоры на руки }\end{array}$ & $\begin{array}{c}\text { Перенос веса в положении сидя } \\
\text { без поддержки }\end{array}$ \\
\hline $\begin{array}{l}\text { Вытягивание грудного отдела } \\
\text { позвоночника. Движения головы, } \\
\text { независимые от туловища. } \\
\text { Опирается на вытянутые руки }\end{array}$ & $\begin{array}{l}\text { Не может оставаться в сидячем } \\
\text { положении долгое время }\end{array}$ & $\begin{array}{l}\text { Перенос веса вперед, назад } \\
\text { или в стороны. Не может } \\
\text { оставаться один в сидячем } \\
\text { положении }\end{array}$ \\
\hline Посадка без опоры на руки (1) & $\begin{array}{l}\text { Попытка дотянуться до предмета } \\
\text { с поворотом в положении сидя }\end{array}$ & Вставание с поддержкой (3) \\
\hline $\begin{array}{l}\text { Руки не прижаты к телу. Способен } \\
\text { играть с игрушкой. Может оста- } \\
\text { ваться один в сидячем положении }\end{array}$ & $\begin{array}{l}\text { Сидит самостоятельно. Тянется } \\
\text { к игрушке с поворотом туловища }\end{array}$ & $\begin{array}{l}\text { Бедра находятся на линии плеч. } \\
\text { Активный контроль туловища. } \\
\text { Разнообразные движения ногами }\end{array}$ \\
\hline Положение лежа на боку с опорой & Реципрокное ползание & $\begin{array}{c}\text { Перемещение из положения } \\
\text { на четвереньках в положение сидя } \\
\text { или полусидя } \\
\end{array}$ \\
\hline $\begin{array}{l}\text { Разобщенность ног. Неподвиж- } \\
\text { ность плеч. Поворот в пределах } \\
\text { оси тела }\end{array}$ & $\begin{array}{l}\text { Реципрокные движения рук и ног } \\
\text { с поворотом туловища }\end{array}$ & $\begin{array}{l}\text { Перемещается в данное положе- } \\
\text { ние и из него. Может принимать } \\
\text { сидячее положение }\end{array}$ \\
\hline
\end{tabular}




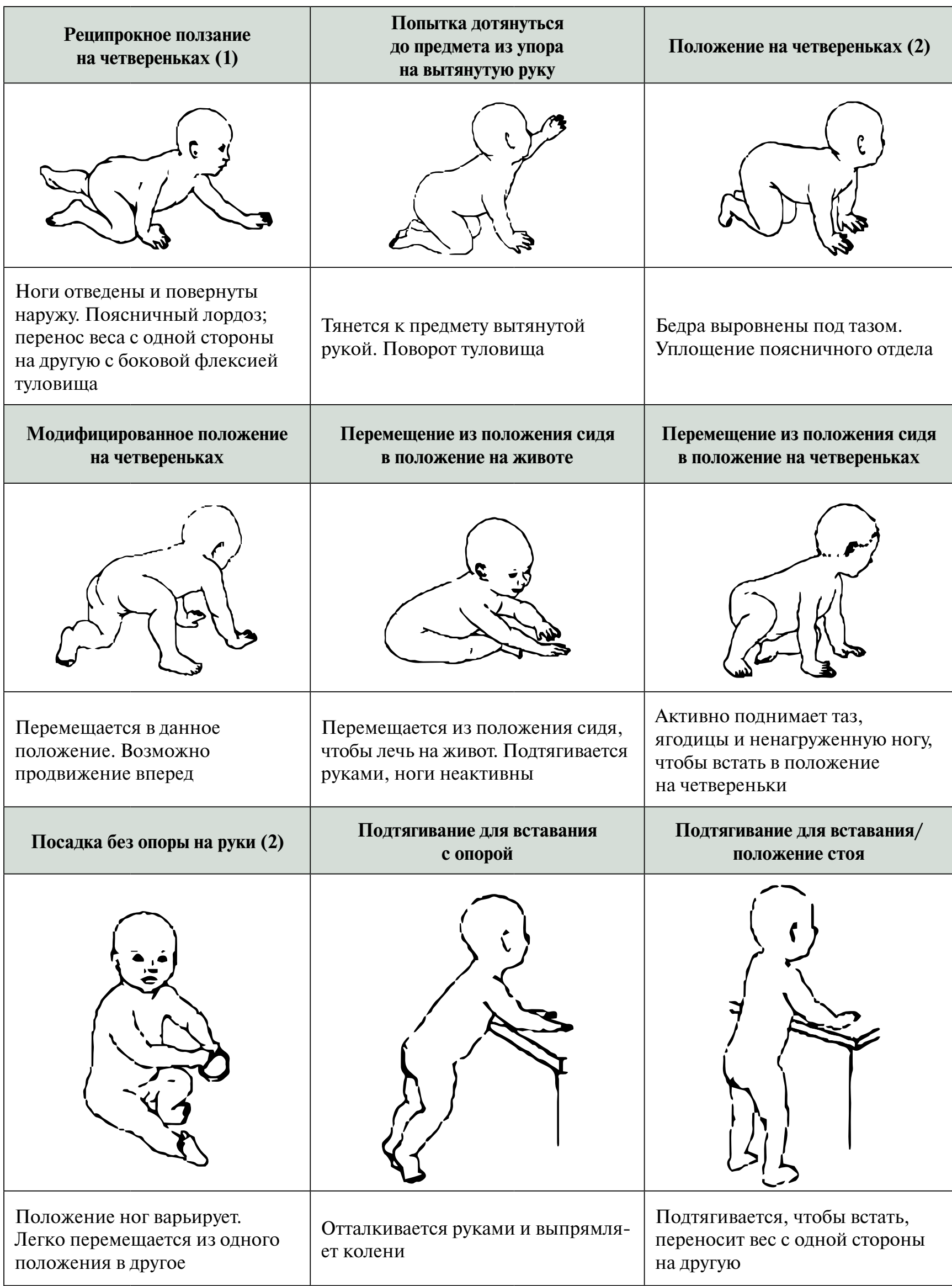




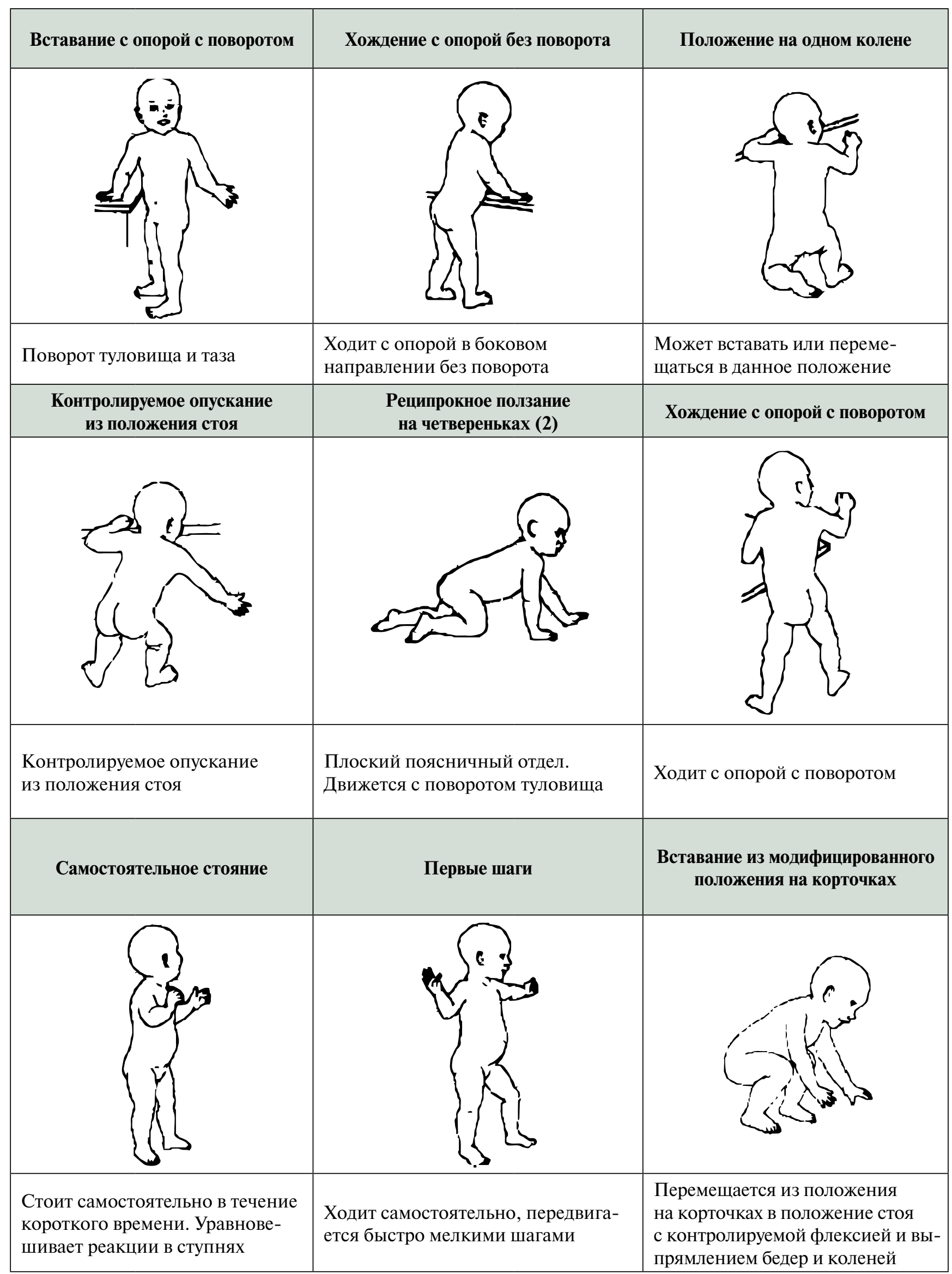




\begin{tabular}{|l|l|}
\hline $\begin{array}{l}\text { Вставание из опоры } \\
\text { на четыре конечности }\end{array}$ & Самостоятельное хождение \\
\hline $\begin{array}{l}\text { Быстро отталкивается ладоня- } \\
\text { ми, чтобы встать }\end{array}$ & Ходит самостоятельно корточках \\
\hline Сохраняет положение, уравнове- \\
\hline
\end{tabular}

График зависимости перцентилей от числа баллов по шкале Альберта моторного развития младенцев

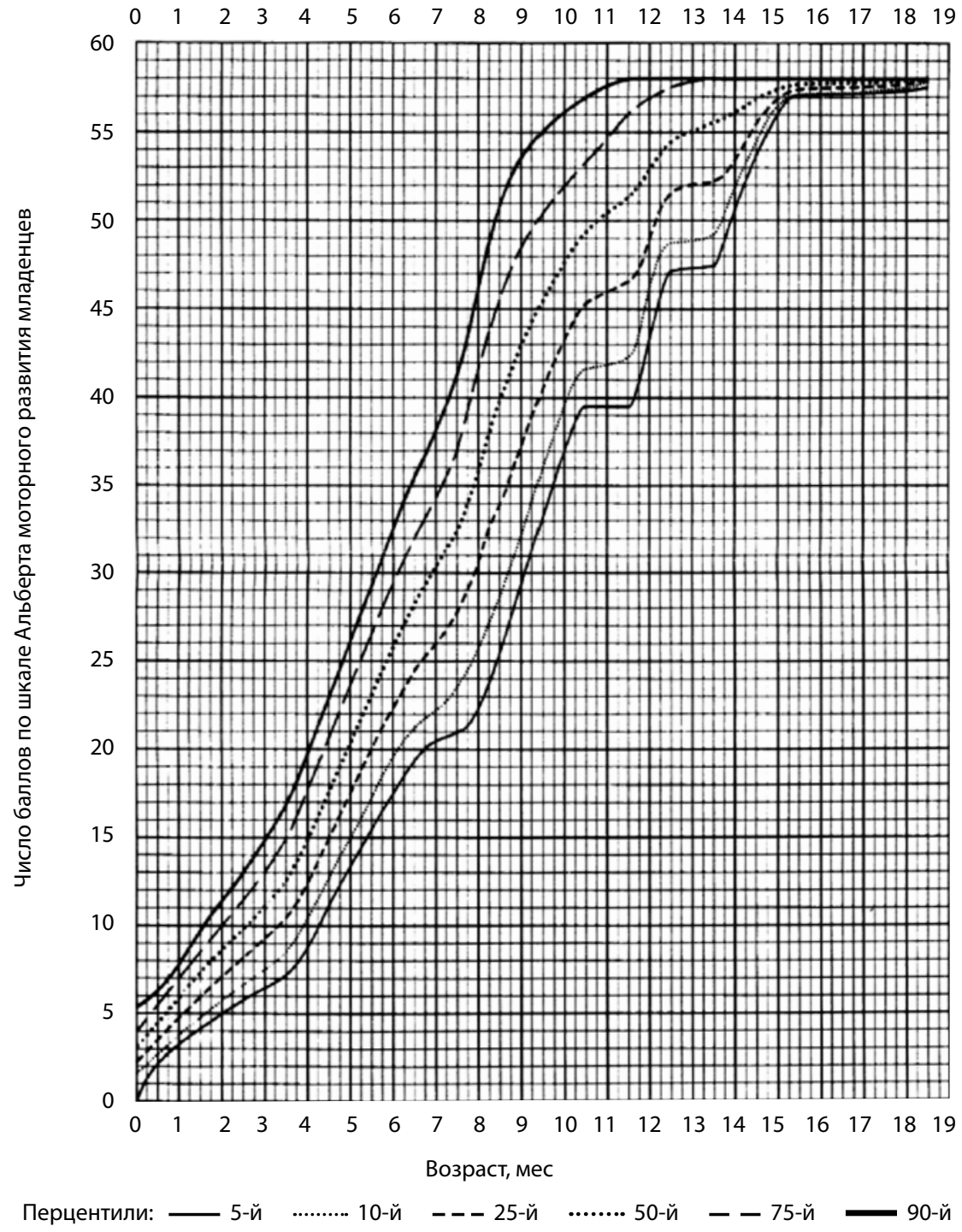


Приложение 2

\section{Сила мышц no шкале Koмumema медuцинских исследований}

\begin{tabular}{|c|l|}
\hline Балл & \multicolumn{1}{c|}{ Оценка силы мышц } \\
\hline 5 & Нормальная сила \\
\hline 4 & Способность поднимать конечность против небольшого сопротивления \\
\hline 3 & Способность поднимать конечность, но не против сопротивления \\
\hline 2 & Движения только в горизонтальной плоскости \\
\hline 1 & Слабое сокращение мышц \\
\hline 0 & Движения отсутствуют \\
\hline
\end{tabular}

Данная шкала позволяет оценить:

• силу исследуемых мышц на момент осмотра в баллах;

• динамику вовлечения отдельных мышц и мышечных групп;

• скорость прогрессирования миопатического процесса. 


\section{Шкала Cкотmа для оценки мышечного сmamyса}

\begin{tabular}{|c|c|}
\hline № & Вид движения пациента \\
\hline 1 & Подъем головы \\
\hline 2 & Поворот со спины на живот через правую сторону \\
\hline 3 & Поворот со спины на живот через левую сторону \\
\hline 4 & Поворот с живота на спину через правую сторону \\
\hline 5 & Поворот с живота на спину через левую сторону \\
\hline 6 & Садится (принимает сидячее положение) \\
\hline 7 & Сидит \\
\hline 8 & Встает (принимает положение стоя) \\
\hline 9 & Стоит \\
\hline 10 & Стоит на пятках \\
\hline 11 & Стоит на носках \\
\hline 12 & Стоит на правой ноге \\
\hline 13 & Стоит на левой ноге \\
\hline 14 & Прыгает на правой ноге \\
\hline 15 & Прыгает на левой ноге \\
\hline 16 & Встает со стула \\
\hline 17 & Восходящий шаг правой ногой \\
\hline 18 & Нисходящий шаг правой ногой \\
\hline 19 & Восходящий шаг левой ногой \\
\hline 20 & Нисходящий шаг левой ногой \\
\hline
\end{tabular}

Шкала Скотта используется для определения общего показателя двигательной активности. При осмотре пациента по таблице оценивается каждый вид движения при самостоятельном выполнении или с посторонней помощью. По результатам исследования присваиваются баллы: 2 балла - за каждое самостоятельно завершенное движение, 1 балл - если была оказана помощь и/или движение потребовало больших усилий, 0 баллов если движение не выполнено. Далее производится подсчет суммы баллов. Максимальное количество баллов 40 , минимальное - 0 . 


\section{Функциональные классы uкалы Вuньоса}

\begin{tabular}{|c|c|}
\hline № & Возможность движения \\
\hline 1 & $\begin{array}{l}\text { Пациент имеет очевидное нарушение осанки и походки, но ходит и поднимается } \\
\text { по ступеням без поддержки }\end{array}$ \\
\hline 2 & Пациент ходит, но поднимается по лестнице с помощью перил \\
\hline 3 & $\begin{array}{l}\text { Пациент ходит, но поднимается по лестнице на } 8 \text { стандартных ступеней } \\
\text { с помощью перил более чем за } 25 \text { с }\end{array}$ \\
\hline 4 & Пациент ходит, но не может подниматься по лестнице \\
\hline 5 & $\begin{array}{l}\text { Пациент ходит без поддержки, но не может поднимать ногу для шага на ступени } \\
\text { или не может вставать с кресла }\end{array}$ \\
\hline 6 & Пациент ходит только в ортопедическом корсете \\
\hline 7 & $\begin{array}{l}\text { Пациент в кресле-каталке. Сидит прямо, может управлять креслом и совершать } \\
\text { все жизненно необходимые действия с кресла }\end{array}$ \\
\hline 8 & $\begin{array}{l}\text { Пациент в кресле-каталке. Сидит прямо, но не может совершать } \\
\text { все жизненно необходимые действия с кресла }\end{array}$ \\
\hline 9 & $\begin{array}{l}\text { Пациент в кресле-каталке. Сидит прямо только при поддержке. } \\
\text { Может совершать минимум жизненно необходимых действий с кресла }\end{array}$ \\
\hline 10 & $\begin{array}{l}\text { Пациент не встает с кровати. Не может совершать жизненно необходимые действия } \\
\text { без посторонней помощи }\end{array}$ \\
\hline
\end{tabular}

Оценка возможностей движения пациента проводится по 10 функциональным классам, представленным в таблице. По завершению исследования выставляется класс, который соответствует двигательной активности больного. 
Приложение 5

\section{Tecm 6-мuнутной ходьбы}

Для теста 6-минутной ходьбы (6-minutes walking test) имеются следующие абсолютные противопоказания: нестабильная стенокардия напряжения и инфаркт миокарда давностью до 1 мес. Относительными противопоказаниями являются частота сердечных сокращений > 120 уд./мин в покое, систолическое АД > 180 мм рт.ст., диастолическое АД > 100 мм рт.ст. При стабильной стенокардии тест следует проводить с осторожностью на фоне приема антиангинальных препаратов по показаниям.

Если пациент находится на постоянной кислородной поддержке, скорость подачи кислорода при проведении теста должна сохраняться в соответствии с предписанием врача, назначившего и контролирующего терапию.

Тест необходимо немедленно прекратить в случае появления:

1) боли в груди;

2) непереносимой одышки;

3) крампи в ногах;

4) резкой неустойчивости и пошатывания при ходьбе;

5) чрезмерного потоотделения;

6) резкого изменения цвета кожных покровов (бледности).

Тест 6-минутной ходьбы проводится в хорошо знакомом пациенту помещении, имеющем достаточно длинный коридор с твердым покрытием. Длина проходимого пути должна составлять $\geq 30$ м с разметкой каждые 3 м, а также точками поворотов/разворотов.

Пациент должен идти с максимально возможной скоростью (но не бежать) в течение 6 мин. Оценивается расстояние в метрах, пройденное за 6 мин без вынужденных остановок. 
Приложение 6

\section{Шкала cmeneнu ycmaлосmu}

Нас интересует роль усталости в Вашей повседневной жизни. Пожалуйста, прочитайте следующие утверждения, затем выберите цифру, наиболее соответствующую Вашему текущему состоянию:

1 - абсолютно не согласен;

2 - скорее не согласен;

3 - частично не согласен;

4 - не могу сказать, что согласен или не согласен;

5 - частично согласен;

6 - скорее согласен;

7 - абсолютно согласен.

\begin{tabular}{|c|c|}
\hline 1. Моя мотивация снижается, когда я испытываю усталость & $\square 1 \square 2 \square 3 \square 4 \square 5 \square 6 \square 7$ \\
\hline 2. Физические упражнения усиливают мою усталость & $\square 1 \square 2 \square 3 \square 4 \square 5 \square 6 \square 7$ \\
\hline 3. Я быстро устаю (утомляюсь) & $\square 1 \square 2 \square 3 \square 4 \square 5 \square 6 \square 7$ \\
\hline 4. Усталость ограничивает мои физические возможности & $\square 1 \square 2 \square 3 \square 4 \square 5 \square 6 \square 7$ \\
\hline 5. Усталость часто становится причиной моих проблем & $\square 1 \square 2 \square 3 \square 4 \square 5 \square 6 \square 7$ \\
\hline $\begin{array}{l}\text { 6. Усталость не позволяет мне жить нормальной физической } \\
\text { жизнью }\end{array}$ & $\square 1 \square 2 \square 3$ \\
\hline $\begin{array}{l}\text { 7. Усталость затрудняет выполнение определенных действий } \\
\text { и обязанностей }\end{array}$ & $\square 1 \square 2 \square 3 \square 4 \square 5 \square 6[$ \\
\hline $\begin{array}{l}\text { 8. Моя усталость является одной из } 3 \text { главных причин } \\
\text { недееспособности }\end{array}$ & $\square 1 \square 2 \square 3 \square 4 \square 5 \square 6 \square$ \\
\hline $\begin{array}{l}\text { 9. Усталость создает трудности на работе, в семье } \\
\text { или в социальной жизни }\end{array}$ & $\square 1 \square 2 \square 3 \square 4 \square 5 \square 6 \square 7$ \\
\hline
\end{tabular}


Приложение 7

\section{Ротmердамская шкала инвалидностu}

По каждому вопросу выберите ответ, лучше всего описывающий Ваше состояние на момент опроса.

Примечание к вопросам 1, 2. Перемещение из одного помещения в другое или вне помещения не обязательно подразумевает, что Вы можете ходить (например, Вы перемещаетесь в кресле-каталке).

\section{1. Перемещение в помещении}

Можете ли Вы перемещаться из одного помещения в другое, справляясь при этом с дверьми, коврами и скользкими поверхностями?

$\square 0$ - неприменимо;

$\square 1$ - не способен перемещаться из одного помещения в другое;

$\square 2$ - перемещаюсь из одного помещения в другое в основном с посторонней помощью;

3 - бо́льшую часть времени самостоятельно перемещаюсь из одного помещения в другое, иногда нуждаюсь в посторонней помощи;

4 - перемещаюсь из одного помещения в другое самостоятельно, без посторонней помощи.

\section{2. Перемещение вне помещения}

Можете ли Вы перемещаться вне помещения из одного места в другое, справляясь при этом с бордюрами и неровными поверхностями?

$\square 0$ - неприменимо;

1 - не способен перемещаться вне помещения;

2 - перемещаюсь вне помещения в основном с посторонней помощью;

3 - большую часть времени самостоятельно перемещаюсь вне помещения, иногда нуждаюсь в посторонней помощи;

4 - перемещаюсь вне помещения из одного места в другое самостоятельно, без посторонней помощи.

\section{3. Использование кухни}

Можете ли Вы приготовить и подать чай/кофе, доставать предметы из верхних и нижних кухонных шкафов, холодильника и т. д. (другие манипуляции на кухне также применимы)?

$\square 0$ - неприменимо;

1 - не способен выполнять никакие действия на кухне;

2 - способен выполнять только самые простые из указанных действий в основном с посторонней помощью;

$\checkmark 3$ - способен самостоятельно выполнять подавляющую часть указанных действий, иногда нуждаюсь в посторонней помощи;

4 - способен самостоятельно выполнять все действия на кухне. 


\section{4. Хозяйственные дела (в помещении)}

Можете ли Вы выполнять такую работу по дому, как уборка пылесосом, мытье посуды, стирка, вытирание пыли и т. д.?

$\square 0$ - неприменимо;

$\square 1$ - не способен выполнять никакие хозяйственные дела в помещении;

$\square 2$ - способен выполнять только самые простые из указанных действий в основном с посторонней помощью;

3 - способен самостоятельно выполнять подавляющую часть указанных действий, иногда нуждаюсь в посторонней помощи;

4 - способен самостоятельно выполнять все хозяйственные дела в помещении.

\section{5. Хозяйственные дела (вне помещения)}

Можете ли Вы делать покупки, работать в саду, мыть машину и т. д.?

$\square 0$ - неприменимо;

1 - не способен выполнять никакие хозяйственные дела вне помещения;

2 - способен выполнять только самые простые из указанных действий в основном с посторонней помощью;

$\square 3$ - способен самостоятельно выполнять подавляющую часть указанных действий, иногда нуждаюсь в посторонней помощи;

$\square 4$ - способен самостоятельно выполнять все хозяйственные дела вне помещения.

\section{6. Досуг (в помещении)}

Можете ли Вы читать газеты, журналы или книги, пользоваться телефоном, заниматься каким-нибудь хобби (кроме спорта)?

$\square 0$ - неприменимо;

$\square 1$ - не способен выполнять указанные действия;

$\square 2$ - способен выполнять только самые простые из указанных действий в основном с посторонней помощью;

3 - способен самостоятельно выполнять подавляющую часть указанных действий, иногда нуждаюсь в посторонней помощи;

4 - способен самостоятельно выполнять все указанные действия.

\section{7. Досуг (вне помещения)}

Можете ли Вы ходить на вечеринки, в театр, кинотеатр, на концерты, в музеи, на встречи, заниматься спортом?

$\square 0$ - неприменимо;

$\square 1$ - не способен выполнять указанные действия;

$\square 2$ - способен выполнять только самые простые из указанных действий в основном с посторонней помощью;

$\square 3$ - способен самостоятельно выполнять подавляющую часть указанных действий, иногда нуждаюсь в посторонней помощи;

4 - способен самостоятельно выполнять все указанные действия. 
Примечание к вопросу 8. При отсутствии водительских прав Вы можете считать это условие вопроса «выполненным», за исключением случаев, когда очевидно, что вождение автомобиля абсолютно невозможно в связи с Вашим заболеванием.

\section{8. Способность водить автомобиль, ездить на автобусе, кататься на велосипеде}

Можете ли Вы водить автомобиль, ездить на автобусе/метро, кататься на велосипеде?

$\square 0$ - неприменимо;

1 - не способен выполнять указанные действия;

2 - способен выполнять только одно из указанных действий (при необходимости с посторонней помощью);

3 - способен выполнять 2 действия из указанных (при необходимости с посторонней помощью);

4 - способен самостоятельно выполнять все указанные действия.

\section{9. Работа/учеба}

Можете ли Вы продолжать заниматься своей привычной (как до заболевания) работой/учебой?

0 - неприменимо;

$\square 1$ - не способен заниматься привычной работой/учебой;

2 - способен частично заниматься адаптированной работой/учебой;

3 - способен частично заниматься привычной работой/учебой;

$\square 4$ - способен заниматься привычной работой/учебой в полном объеме.

Использование шкал приложений 1-7 носит рекомендательный характер. В связи с низкой выявляемостью болезни Помпе в России валидизация данных шкал не проводилась. 


\section{Onpocнuк SF-36. Оценка качества жизни (русскоязычная версия, созданная и рекомендованная Межнациональным центром исследования качества жизни)}

Этот опросник содержит вопросы, касающиеся Ваших взглядов на свое здоровье. Предоставленная Вами информация поможет следить за тем, как Вы себя чувствуете и насколько хорошо справляетесь со своими обычными нагрузками. Ответьте на каждый вопрос, помечая выбранный Вами ответ, как это указано. Если Вы не уверены в том, как ответить на вопрос, пожалуйста, выберите такой ответ, который точнее всего отражает Ваше мнение.

1. В целом Вы бы оценили состояние Вашего здоровья как (обведите одну цифру):

1 - отличное;

2 - очень хорошее;

3 - хорошее;

4 - посредственное;

5 - плохое.

2. Как бы Вы оценили свое здоровье сейчас по сравнению с тем, что было год назад (обведите одну цифру)?

1 - значительно лучше, чем год назад;

2 - несколько лучше, чем год назад;

3 - примерно так же, как год назад;

4 - несколько хуже, чем год назад;

5 - гораздо хуже, чем год назад.

3. Следующие вопросы касаются физических нагрузок, с которыми Вы, возможно, сталкиваетесь в течение своего обычного дня.

Ограничивает ли Вас состояние Вашего здоровья в настоящее время в выполнении перечисленных ниже физических нагрузок? Если да, то в какой степени (обведите одну цифру в каждой строке)?

\begin{tabular}{|c|l|c|c|c|}
\hline \multicolumn{1}{|c|}{ Вид физической активности } & $\begin{array}{l}\text { Да, значительно } \\
\text { ограничивает }\end{array}$ & $\begin{array}{c}\text { Да, немного } \\
\text { ограничивает }\end{array}$ & $\begin{array}{c}\text { Нет, совсем } \\
\text { не ограничивает }\end{array}$ \\
\hline А & $\begin{array}{l}\text { Тяжелые физические нагрузки, такие как бег, } \\
\text { поднятие тяжестей, занятие силовыми видами } \\
\text { спорта }\end{array}$ & 1 & 2 & 3 \\
\hline Б & $\begin{array}{l}\text { Умеренные физические нагрузки, такие как пере- } \\
\text { двинуть стол, поработать с пылесосом, собирать } \\
\text { грибы или ягоды }\end{array}$ & 1 & 2 & 3 \\
\hline В & $\begin{array}{l}\text { Поднять или нести сумку с продуктами } \\
\text { Г }\end{array} \begin{array}{l}\text { Подняться пешком по лестнице на несколько } \\
\text { пролетов }\end{array}$ & 1 & 2 & 3 \\
\hline Д & Подняться пешком по лестнице на один пролет & 1 & 2 & 3 \\
\hline
\end{tabular}




\begin{tabular}{|c|l|c|c|}
\hline Е & Наклониться, встать на колени, присесть на корточки & 1 & 2 \\
\hline Ж & Пройти расстояние более одного километра & 1 & 2 \\
\hline 3 & Пройти расстояние в несколько кварталов & 1 & 2 \\
\hline И & Пройти расстояние в один квартал & 1 & 2 \\
\hline К & Самостоятельно вымыться, одеться & 1 & 3 \\
\hline
\end{tabular}

4. Бывало ли за последние 4 недели, что Ваше физическое состояние вызывало затруднения в Вашей работе или другой обычной повседневной деятельности, вследствие чего (обведите одну цифру в каждой строке):

\begin{tabular}{|c|l|c|c|}
\hline & \multicolumn{1}{|l|}{ Да } & Нет \\
\hline А & $\begin{array}{l}\text { Пришлось сократить количество времени, затрачиваемого на работу } \\
\text { или другие дела }\end{array}$ & 1 & 2 \\
\hline Б & Выполнили меньше, чем хотели & 1 & 2 \\
\hline В & $\begin{array}{l}\text { Вы были ограничены в выполнении какого-либо определенного вида } \\
\text { работы или другой деятельности }\end{array}$ & 1 & 2 \\
\hline$\Gamma$ & $\begin{array}{l}\text { Были трудности при выполнении своей работы или других дел } \\
\text { (например, они потребовали дополнительных усилий) }\end{array}$ & 1 & 2 \\
\hline
\end{tabular}

5. Бывало ли за последние 4 недели, что Ваше эмоциональное состояние вызывало затруднения в Вашей работе или другой обычной повседневной деятельности, вследствие чего (обведите одну цифру в каждой строке)?

\begin{tabular}{|l|l|c|c|}
\hline & \multicolumn{1}{|l|}{ Да } & Нет \\
\hline А & $\begin{array}{l}\text { Пришлось сократить количество времени, затрачиваемого на работу } \\
\text { или другие дела }\end{array}$ & 1 & 2 \\
\hline Б & Выполнили меньше, чем хотели & 1 & 2 \\
\hline В & Выполняли свою работу или другие дела не так аккуратно, как обычно & 1 & 2 \\
\hline
\end{tabular}

6. Насколько Ваше физическое или эмоциональное состояние в течении последних 4 недель мешало Вам проводить время с семьей, друзьями, соседями или в коллективе (обведите одну цифру)?

1 - совсем не мешало;

2 - немного

3 - умеренно;

4 - сильно;

5 - очень сильно. 
7. Насколько сильную физическую боль Вы испытывали за последние 4 недели (обведите одну цифру)?

1 - совсем не испытывал(-а);

2 - очень слабую;

3 - слабую;

4 - умеренную;

5 - сильную;

6 - очень сильную.

8. В какой степени боль в течение последних 4 недель мешала Вам заниматься Вашей нормальной работой, включая работу вне дома и по дому (обведите одну цифру)?

1 - совсем не мешала;

2 - немного;

3 - умеренно;

4 - сильно;

5 - очень сильно.

9. Следующие вопросы касаются того, как Вы себя чувствовали и каким было Ваше настроение в течение последних 4 недель. Пожалуйста, на каждый вопрос дайте один ответ, который наиболее соответствует Вашим ощущениям.

Как часто в течении последних 4 недель (обведите одну цифру в каждой строке):

\begin{tabular}{|l|l|c|c|c|c|c|c|}
\hline & & $\begin{array}{c}\text { Все } \\
\text { время }\end{array}$ & $\begin{array}{c}\text { Большую } \\
\text { часть } \\
\text { времени }\end{array}$ & Часто & Иногда & Редко & Ни разу \\
\hline А & Вы чувствовали себя бодрым(-ой)? & 1 & 2 & 3 & 4 & 5 & 6 \\
\hline Б & Вы сильно нервничали? & 1 & 2 & 3 & 4 & 5 & 6 \\
\hline В & $\begin{array}{l}\text { Вы чувствовали себя таким(-ой) } \\
\text { подавленным(-ой), что ничто не могло } \\
\text { Вас взбодрить? }\end{array}$ & 1 & 2 & 3 & 4 & 5 & 6 \\
\hline Г & $\begin{array}{l}\text { Вы чувствовали себя спокойным(-ой) } \\
\text { и умиротворенным(-ой)? }\end{array}$ & 1 & 2 & 3 & 4 & 5 & 6 \\
\hline Д & $\begin{array}{l}\text { Вы чувствовали себя полным(-ой) сил } \\
\text { и энергии? }\end{array}$ & 1 & 2 & 3 & 4 & 5 & 6 \\
\hline Е & $\begin{array}{l}\text { Вы чувствовали себя упавшим(-ей) духом } \\
\text { и печальным (ой)? }\end{array}$ & 1 & 2 & 3 & 4 & 5 & 6 \\
\hline Ж & Вы чувствовали себя измученным(-ой)? & 1 & 2 & 3 & 4 & 5 & 6 \\
\hline 3 & Вы чувствовали себя счастливым(-ой)? & 1 & 2 & 3 & 4 & 5 & 6 \\
\hline И & Вы чувствовали себя уставшим(-ей)? & 1 & 2 & 3 & 4 & 5 & 6 \\
\hline
\end{tabular}




\section{0. Как часто в последние 4 недели Ваше физическое или эмоциональное состояние мешало Вам активно общаться с людьми? Например, навещать родственников, друзей и т. п. (обведите одну цифру).}

1 - все время;

2 - большую часть времени;

3 - иногда;

4 - редко;

5 - ни разу.

\section{1. Насколько ВЕРНЫМ или НЕВЕРНЫМ представляется по отношению к Вам каждое из ниже перечисленных утверждений (обведите одну цифру в каждой строке)?}

\begin{tabular}{|l|l|c|c|c|c|c|}
\hline & \multicolumn{1}{|l|}{$\begin{array}{c}\text { Определенно } \\
\text { верно }\end{array}$} & $\begin{array}{c}\text { В основном } \\
\text { верно }\end{array}$ & Не знаю & $\begin{array}{c}\text { В основном } \\
\text { не верно }\end{array}$ & $\begin{array}{c}\text { Определенно } \\
\text { неверно }\end{array}$ \\
\hline А & $\begin{array}{l}\text { Мне кажется, что я более склонен } \\
\text { к болезням, чем другие }\end{array}$ & 1 & 2 & 3 & 4 & 5 \\
\hline Б & $\begin{array}{l}\text { Мое здоровье не хуже, чем у боль- } \\
\text { шинства моих знакомых }\end{array}$ & 1 & 2 & 3 & 4 & 5 \\
\hline В & $\begin{array}{l}\text { Я ожидаю, что мое здоровье } \\
\text { ухудшится }\end{array}$ & 1 & 2 & 3 & 4 & 5 \\
\hline Г & У меня отличное здоровье & 1 & 2 & 3 & 4 & 5 \\
\hline
\end{tabular}

\section{Л И TEPAT У PA / REFERE NEES}

1. ATS Committee on Proficiency Standards for Clinical Pulmonary Function Laboratories. ATS Statement: Guidelines for the Six-Minute Walk Test. Am J Respir Crit Care Med 2002;166(2):111-7.

2. Byrne B.J., Kishnani P.S., Case L.E. et al. Pompe disease: design, methodology, and early findings from the Pompe Registry. Mol Genet and Metab 2011;103(1):1-11. 3. Bembi B., Cerini E., Danesino C. et al. Management and treatment of glycogenosis type II. Neurology 2008;71(Suppl 2):12-36. 4. Byrne B.J., Kishnani P.S., Case L.E. et al. Pompe disease: Design, methodology, and early findings from the Pompe Registry. Mol Genet Metab 2011;103(1):1-11.

5. Barba-Romero M.A., Barrot E., Bautista-Lorite J. et al. Clinical guidelines for late-onset Pompe disease. Rev Neurol 2012;54(8):4970-507.

6. Chien Y.H., Lee N.C., Thurberg B.L. et al. Pompe disease in infants: Improving the prognosis by newborn screening and early treatment. Pediatrics 2009;124(6): e1116-25.

7. Cupler E.J., Berger K.I., Leshner R.T.

et al. Consensus treatment recommendations for late-onset Pompe disease. Muscle Nerve 2012;45(3):319-33.

8. Desnuelle C. Поздняя форма болезни Помпе: диагностические и терапевтические подходы. Нервно-мышечные болезни 2012;(3):20-33.

9. de Vries J.M., van der Beek N.A. Hop W.C. et al. Effect of enzyme therapy and prognostic factors in 69 adults with Pompe disease: an open-label single-center study. Orphanet J Rare Dis 2012;7:73.

10. Deegan P.B., Cox T.M., Waldek S. et al. Guidelines for the Investigation and Management of Late Onset Acid Maltase Deficiency (Type II Glycogen Storage Disease/Pompe Disease). Available at: http://www.specialisedservices.nhs.uk/ library/23/Guidelines_for_Late_Onset_ Pompe_Disease.pdf.

11. Gungor D., Krujushaar M.E., Plug I. et al. Impact of enzyme replacement therapy on survival in adults with Pompe disease: results from a prospective international observational study. Orphanet J Rare Dis 2013;8(1):49.
12. Hagemans M.L., Winkel L.P., Hop W.C. et al. Disease severity in children and adults with Pompe disease related to age and disease duration. Neurology 2005;64(12):2139-41.

13. Hirschorn R., Reuser A.J. Glycogen Storage Disease type II: Acid $\alpha$-glucosidase (acid maltase) deficiency. By eds.: C.R. Sriver, A.L. Beaudet, W.S. Sly, D. Valle. In: The Metabolic and Molecular Basis of Inherited Disease, $8^{\text {th }}$ ed. Pp. 3389-420. 14. Kishnani P.S., Corzo D., Leslie N.D. et al. Early treatment with alglucosidase alfa prolongs long-term survival of infants with Pompe disease. Pediatr Res 2009;66(3):329-35. 15. Kishnani P.S., Steiner R.D., Bali D. et al. Pompe disease diagnosis and management guideline. Genet Med 2006;8(5):267-88. 16. Llerena J.C., Horovitz D. M., Marie S.K. et al. The Brazilian consensus on the management of Pompe disease. J Pediatr 2009;155(4):47-56

17. Pompe Disease Diagnostic

Working Group, Winchester B., Bali D. et al. Methods for a prompt and reliable laboratory diagnosis of Pompe disease: 
Report from an international consensus meeting. Mol Genet Metab 2008;93(3): 275-81.

18. Muller-Felber W., Horvath R., Gempel K. et al. Late onset Pompe disease: clinical and neurophysiological spectrum of 38 patients including long-term follow-up in 18 patients. Neuromuscul Disord 2007;17:698-706.

19. Nicolino M., Byrne B., Wraith J.E. et al. Clinical outcomes after long-term treatment with alglucosidase alfa in infants and children with advanced Pompe disease. Genet Med 2009;11(3):210-9.
20. Winkel L.P., Hagemans M.L., van Doorn P.A. et al. The natural course of non-classic Pompe's disease; a review of 225 published cases. J Neurol 2005;252(8): 875-84.

21. Басаргина Е.Н., Жарова О.П., Архипова Е.Н. и др. Опыт применения ферментозаместительной терапии рекомбинантной человеческой кислой альфа-глюкозидазой у детей с инфантильной формой болезни Помпе. Российский вестник перинатологии и педиатрии 2013;(6):58-66.
22. Басаргина Е.Н., Архипова Е.Н., Ермоленко В.С. Болезнь Помпе - новый взгляд на проблему. Фарматека 2014;(1):29-32. 23. Котлукова Н.П., Михайлова С.В., Букина Т.М. и др. Младенческая форма болезни Помпе: клиника, диагностика и лечение. Нервно-мышечные болезни 2012;(4):66-74.

24. Никитин С.С., Ковальчук М.О., Захарова Е.Ю. и др. Болезнь Помпе с поздним началом: первое клиническое описание в России. Нервно-мышечные болезни 2014;(1):62-8. 